\title{
Kto założył miasto Częstochowę? Przyczynek do urbanizacji Małopolski w XIV wieku
}

I. Przed 17 laty ukazała się monografia Częstochowy, a w opublikowanych w niej tekstach ugruntowany został pogląd, że miasto lokował książę Władysław Opolczyk ${ }^{1}$. Wydawać by się mogło, że jest to ustalenie bezsporne. Tymczasem jeszcze kilka lat wcześniej krakowski mediewista Jacek Laberschek wysunął przekonującą hipotezę, że założycielem miasta Częstochowy mógł być Kazimierz Wielki². Do koncepcji o Kazimierzowskiej lokacji Częstochowy wspomniany badacz powrócił krótko po opublikowaniu monografii (której był zresztą współautorem), w artykule o częstochowskim zespole osadniczym $^{3}$. Można w pewnym sensie stwierdzić, że Laberschek niejako wszedł

${ }^{1}$ Częstochowa. Dzieje miasta i Klasztoru Jasnogórskiego. T. 1: Okres staropolski. Red. F. KiRYK. Częstochowa 2002. Chodzi zwłaszcza o dwa artykuły Marcelego Antoniewicza: Narodziny miasta (s. 121-140) oraz Heraldyka Częstochowy w okresie przedrozbiorowym (s. 540-549), a także tekst Jacka LaberscheKa: Początki Częstochowy na tle stosunków osadniczych (s. 108-109, 112-115).

2 J. LABerscheK: Nowe spojrzenie na początki miasta Częstochowy. „Almanach Częstochowy" 1994, s. 5-17. W nieznacznie zmienionej wersji tego tekstu autor w większości powtórzył argumenty (TenżE: Nowe spojrzenie na początki Częstochowy. W: TenżE: Częstochowa $i$ jej okolice $w$ średniowieczu. Kraków 2006, s. 13-25). Warto zaznaczyć, że dużo wcześniej Kazimierza Wielkiego za założyciela Częstochowy uznał Feliks KIRYK, datując ten fakt przed 1377 r., zob. TenżE: Polityka miejska Kazimierza Wielkiego w Małopolsce. W: Problemy dziejów i konserwacji miast zabytkowych. Materiały II Sympozjum Miast Kazimierzowskich w Radomiu i Kazimierzu Dolnym 23-24 września 1988 roku. Red. R. SzCzyGię. Radom-Kazimierz Dolny 1990, s. 13.

3 J. LABerscheK: Częstochowski zespół osadniczy w średniowieczu. „Almanach Częstochowy" 2002, s. 7-8. 
w polemikę z samym sobą, gdyż właśnie to on jako pierwszy stwierdził, iż „za budowniczego miasta Częstochowy należy raczej uznać księcia śląskiego", czyli Władysława Opolczyka ${ }^{4}$. Warto jednak podkreślić, że autor mimo zmiany stanowiska nadal nie wykluczył Władysława Opolczyka, ale starał się wykazać, iż bardziej prawdopodobne i lepiej uzasadnione jest uznanie za założyciela miasta Kazimierza Wielkiego. Jednak pogląd tego badacza nie spotkał się z oddźwiękiem w opracowaniach naukowych. W zasadzie jedynie w książce o starostwie olsztyńskim nawiązałem do tej hipotezy w kontekście przedstawienia rozwoju osadnictwa na obszarze okręgu podlegającego zamkowi Olsztyn w XIV wieku. Zaproponowałem też pewne dodatkowe argumenty wspierające pogląd o założeniu miasta Częstochowy przez ostatniego koronowanego Piasta. W monografii tej jednak nie było miejsca na szczegółowe zajęcie się tą kwestią̧

Niniejszy artykuł stanowi zatem próbę ponownego zweryfikowania genezy miasta Częstochowy. Istotnie bowiem problem ten jest zdecydowanie dyskusyjny. Sprawa początków miasta nie jest bynajmniej oczywista i wiąże się z nią sporo pytań oraz wątpliwości. Pierwszą zagadką jest brak tradycji miejskiej o założycielu miasta i o pierwotnym dokumencie lokacyjnym. Nie było jej już co najmniej w XVI wieku, gdyż przy okazji lustracji królewskich mieszczanie nigdy nie wspominali o pierwotnym fundatorze. Wskazując podstawę ustrojową dla miasta, powoływali się oni wyłącznie na dokument odnowienia prawa magdeburskiego króla Aleksandra Jagiellończyka z 1502 roku. Jest to dość zaskakujące. Fakt odnowienia prawa niemieckiego na początku XVI wieku nie powinien przecież powodować zatarcia w świadomości mieszczan początków tego ośrodka, a więc i osoby fundatora.

II. Choć z powodu istnienia klasztoru Paulinów na Jasnej Górze Częstochowa była przedmiotem zainteresowania historyków już od dawna ${ }^{6}$, to jednak pierwsze opracowania naukowe traktujące o niej powstały dopiero w XX wie$\mathrm{ku}$, a ściślej — bezpośrednio przed II wojną światową. Niezwykle cenne uwagi do dziejów osadnictwa na terenie dzisiejszej Częstochowy poczynił ks. Jan Fijałek w komentarzu do edycji dokumentów dotyczących klasztoru Paulinów. Wyraził przy tym przekonanie, że to właśnie ostatni Piast na polskim tronie

${ }^{4}$ J. LABERSCHEK: Zasięg i charakterystyka rządów Władysława Opolczyka w pótnocno-zachodniej części ziemi krakowskiej 1370-1391. „Rocznik Muzeum Okręgowego w Częstochowie. Historia" 1985, z. 1, s. 19-21, cyt.: s. 19. Można nawet powiedzieć, że podniesione przez Laberscheka argumenty przemawiające za Opolczykiem jako założycielem miasta, w tym również symbolikę pieczęci miejskiej (wskazaną za badaniami M. HAISIGA: Herb miasta Częstochowy. Jego geneza i symbolika. „Ziemia Częstochowska” 1967, T. 6-7, s. 180-190), powtórzył później M. Antoniewicz.

${ }^{5}$ K. Nabiatek: Starostwo olsztyńskie od XIV do połowy XVII wieku. Kraków 2012, s. $80-86$.

${ }^{6}$ M. BALińsKi: Pielgrzymka do Jasnej Góry w Częstochowie odbyta przez pątnika z XIX wieku. Warszawa 1846. 
założył miasto nad Wartą, choć nie podał dla tego stwierdzenia uzasadnienia. Jedną z pierwszych osób, która dokonała naukowej analizy źródeł dotyczących częstochowskiego skupiska osadniczego, była Krystyna Pieradzka, jednak w centrum jej zainteresowania był klasztor jasnogórski, o osadnictwie zaś wspomniała tylko marginalnie. $Z$ tego powodu autorka, nie wnikając głęboko w szczegóły i bazując na przygotowanych do druku przez ks. Fijałka dokumentach paulińskich, ale inaczej niż ten historyk, stwierdziła, ,że za czasów Opolczyka powstało tu miasto pomiędzy 1370 a 1377 r."

Dopiero okres po II wojnie światowej przyniósł szczegółowe prace naukowe dotyczące dziejów osadnictwa na tym obszarze, w tym przedstawienie kwestii genezy i rozwoju miasta. Chodzi tu zwłaszcza o monografię Częstochowy w średniowieczu i w okresie wczesnonowożytnym autorstwa Stefana Krakowskiego ${ }^{9}$. Z powodu słabego rozpoznania zarówno dziejów tej części ziemi krakowskiej czy ogólnie rozumianego pogranicza małopolsko-śląsko-wielkopolskiego, jak i związanych z tym obszarem źródeł, łódzki historyk odtwarzał dzieje Częstochowy niejako bez znajomości kontekstu. W konsekwencji braku badań źródłoznawczych uznał bez zastrzeżeń wiarygodność dokumentu biskupa Iwona Odrowąża z 1220 roku, zatwierdzającego dziesięciny przysługujące prepozyturze mstowskiej klasztoru Kanoników regularnych na Piasku we Wrocławiu. Obecnie wiemy, że edycja tego dyplomu została przygotowana na podstawie zepsutej, interpolowanej wersji, w której pojawiła się, obok rzeczywiście istniejącej wsi Częstochowy, również nieistniejąca wieś Częstochówka. Wychodząc od tych danych, Krakowski błędnie zrekonstruował chronologię osadnictwa częstochowskiego, a w efekcie po publikacji jego książki (1948) w literaturze na długi czas zakorzeniło się nieporozumienie dotyczące najstarszej osady o nazwie Częstochowa ${ }^{10}$. Według koncepcji tego autora wieś Częstochowa, nazywana w XIV wieku Starą Częstochową, była to osada nad Wartą, na bazie której powstało miasto. Niezależnie od Częstochowy w XIII wieku miała istnieć wieś Częstochówka, którą w 1382 roku książę

${ }^{7}$ ZDPaul, s. 5.

${ }^{8}$ K. PieradzKa: Fundacja klasztoru jasnogórskiego w Częstochowie w 1382 r. Kraków 1939, s. 24-29 (cyt.: s. 26).

9 S. Krakowski: Stara Częstochowa. Studia nad geneza, ustrojem i struktura ludnościowa i gospodarcza Częstochowy (1220-1655). Częstochowa 1948.

${ }_{10}$ Tamże, s. 24-46; S. Krakowski: Dzieje Częstochowy od wieku XII do połowy XIX. W: Dzieje Częstochowy od zarania do czasów współczesnych. Katowice 1964, s. 28-32; TenżE: „Region częstochowski” w wiekach XII-XVIII. Prawidtowości i specyfika procesów urbanizacyjnych. W: Stowianie $w$ dziejach Europy. Studia historyczne ku uczczeniu 75 rocznicy urodzin i 50-lecia pracy naukowej profesora Henryka Łowmiańskiego. Poznań 1974, s. 202204. Konstrukcję Krakowskiego powtarzali: J. BraUn: Częstochowa. Zarys architektoniczny i urbanistyczny. Warszawa 1959, s. 15-18; TenżE: Częstochowa. Architektura i urbanistyka. Warszawa 1977, s. 13-18 (oraz późniejsze wydania); E. Wartalska: Dzieje Częstochówki (1220-1655). W: Częstochowa i jej miejsce w kulturze polskiej. Częstochowa 1990, s. 24-28. 
opolski przekazał klasztorowi Paulinów ${ }^{11}$. W ujęciu Krakowskiego wieś Częstochowa została przekształcona w miasto, a przywilej lokacyjny został wystawiony w latach 1370 — 1377, najpewniej przez króla Ludwika Węgierskiego, choć historyk ten nie wykluczał też osoby Kazimierza Wielkiego ${ }^{12}$. W wyniku błędnego założenia, że wieś Częstochowę wzmiankowaną w 1220 roku należy lokalizować nad Wartą, badacz ten uznał później, że powstanie miasta poprzedziła w 1356 roku lokacja na prawie niemieckim wsi Częstochowy nad Wartą i drugiej wsi nad rzeką Stradomką (określonej jako „Rybna”), które następnie zostały połączone i ,uzyskały rangę miejską z inspiracji księcia Władysława Opolczyka"13.

Nie wnikając w szczegółową analizę tej sprawy, którą już dokładnie przedstawiono $\mathrm{w}$ opracowaniach, można stwierdzić, że pogląd S. Krakowskiego o istnieniu w 1220 roku dwóch wsi, Częstochowy oraz Częstochówki, został definitywnie odrzucony. Nie jest już obecnie kwestionowane ustalenie, że najstarszą osadą wzmiankowaną w 1220 roku była wieś Częstochowa usytuowana w pobliżu wzgórza, na którym później powstał klasztor Paulinów, w 2. poł. XIV wieku określana jako Stara Częstochowa, a od XV wieku nazywana Częstochówką, i że to właśnie jej dotyczył przywilej prawa niemieckiego z 1356 roku. Zgodnie przyjmuje się również, że na obszarze późniejszego miasta Częstochowy, założonego nad Wartą, nie tylko w 1220 roku nie było wsi, ale też, że do 1. poł. XIV wieku nie było tam w ogóle osadnictwa. Do sformułowania nowych ustaleń doprowadziły przede wszystkim badania Zofii Leszczyńskiej-Skrętowej, Marcelego Antoniewicza i Jacka Laberscheka. Pierwsza badaczka wskazała na możliwość interpolacji dokumentu z 1220 roku, podpierając się ustaleniami językoznawców, którzy dowiedli anachroniczności dla XIII wieku zdrobniałej nazwy dzierżawczej „Częstochówka”"14. Z kolei Antoniewicz najpierw w popularnonaukowej pracy dotyczącej heraldyki miejskiej pisał, że kolebką całego zespołu osadniczego była wieś usytuowana przy wzgórzu jasnogórskim, miasto nad Wartą zaś założono w wyniku translacji osadnictwa. Przy tym w nieco zawoalowany sposób zasugerował, że lokacji dokonał książę Władysław Opolczyk ${ }^{15}$. Później w odrębnym artykule historyk ten $\mathrm{z}$ jednej strony w przekonujący sposób uzasadnił istnienie w 1220 roku jednej tylko wsi Częstochowy, tożsamej z późniejszą Częstochówką, a z dru-

11 S. Krakowski: Stara Częstochowa..., s. 24-29.

12 Tamże, s. 32-46.

13 S. Krakowski: Dzieje Częstochowy..., s. 28-32; TenżE: „Region częstochowski”..., s. $203-204$.

${ }^{14}$ Z. LeszCZyńSKa-Skrętowa: Częstochowa Stara. W: SHGKr, Cz. 1, s. 470—471; K. Rymut: Nazwy miejscowe pótnocnej części dawnego województwa krakowskiego. Wrocław 1967, s. 40, 272.

${ }^{15}$ M. Antoniewicz: Herby miast województwa częstochowskiego. Częstochowa 1984, s. $27-28$. 
giej sformułował nową propozycję szerzenia się prawa niemieckiego na terenie dzisiejszej Częstochowy. Wysunął mianowicie hipotezę, że na mocy przywileju Kazimierza Wielkiego z 1356 roku drugą wieś w dziedzictwie Częstochowy lokowano nad rzeką Wartą, a następnie na bazie tej wsi przeprowadzono lokację miasta, być może dokonując przy tym jej nieznacznej translacji. Antoniewicz przyjął, że wymieniona w dokumencie królewskim rzeka Rybna mogła odnosić się do nazwy odcinka Warty lub nieistniejącego już dziś cieku wodnego, uchodzącego do Warty nieco bardziej na północ od zabudowy miejskiej; właśnie $\mathrm{w}$ tym drugim wypadku wytyczenie miasta mogłoby się wiązać z nieznaczną translacją. Formułując odważną hipotezę, nie zdecydował się jednak badacz na wskazanie osoby, która zadecydowała o powstaniu ośrodka miejskiego, poprzestając na stwierdzeniu, że nastąpiło to przed 1377 rokiem $^{16}$.

Wspomniane tezy rozwinął jeszcze J. Laberschek, który ponad wszelką wątpliwość potwierdził hipotezę o interpolacji dokumentu z 1220 roku. $\mathrm{W}$ pełni też zaakceptował i poparł dodatkowymi argumentami chronologię osadniczą na obszarze Częstochowy czy, jak sam to nazwał, „częstochowskiego zespołu osadniczego"17. Natomiast pogląd krakowskiego historyka na temat samej lokacji miasta zmieniał się. Najpierw w publikacji ogłoszonej w 1985 roku za założyciela miasta Częstochowy uznał księcia Władysława Opolczy$\mathrm{ka}$, datując lokację w przedziale lat $1372-1377^{18}$. Po niemal dekadzie zmienił zdanie, dowodząc, że proces ten mógł jednak przeprowadzić jeszcze Kazimierz Wielki, przy czym nie odrzucił możliwości udziału Opolczyka w tym przedsięwzięciu ${ }^{19}$. Nieco wyprzedzając tok wywodu, należy zauważyć, że Laberschek wkrótce wycofał się z tego stanowiska, ponownie opowiadając się za działaniami księcia opolskiego ${ }^{20}$, a następnie po pewnym czasie jednak wrócił do hipotezy o Kazimierzowskiej genezie Częstochowy. W trzech opublikowanych tekstach $(2002,2004,2013)$ historyk ten teraz już dość zdecydowanie zakwestionował możliwość dokonania lokacji miasta Częstochowy przez Władysława Opolczyka, przytaczając szereg argumentów za przeprowadzeniem jej przez Kazimierza Wielkiego - o czym dalej.

M. Antoniewicz z kolei w swoim artykule o narodzinach miasta zamieszczonym w monografii Częstochowy mocno dowodził, że założycielem był

${ }^{16}$ M. Antoniewicz: Subregion częstochowski w średniowieczu (XIV-XV wiek). W: Częstochowa i jej miejsce w kulturze polskiej..., s. 10-15.

17 J. LABERSCHEK, rec.: Czesstochowa i jej miejsce w kulturze polskiej, Częstochowa 1990. Kw. Hist. 1991, T. 98, s. 135-136; TenżE: Sieć osadnicza okolic Mstowa i Lelowa w I polowie XIII wieku. Problem granic opola mstowskiego. St. Hist. 1991, T. 34, nr 4, s. 518 - 524; TenżE: Częstochowski zespót osadniczy..., s. 7-8.

18 J. LABERSCHEK: Zasięg i charakterystyka rzadów Wtadysława Opolczyka..., s. 19-21.

19 J. LABERSCHEK: Nowe spojrzenie na początki miasta Częstochowy..., s. 5-17.

20 J. LABERSCHEK: Rycerstwo Częstochowy i jej najbliższych okolic (przełom XIV i XV wieku). „Teki Krakowskie” 1997, T. 5, s. 105-107; TenżE: Początki Częstochowy na tle stosunków osadniczych..., s. 108-109, 112-115. 
książę opolski. Należy podkreślić, że historyk ten wszechstronnie i drobiazgowo przedstawił kontekst oraz okoliczności związane z genezą Częstocho$w^{21}$. Widać jednak w jego narracji wyraźną tendencję do wykazania, że założycielem miasta był właśnie Władysław Opolczyk. Wszystkie podnoszone kwestie wspomniany badacz interpretuje na korzyść tego księcia. Warto przytoczyć jego argumenty. W 1377 roku Częstochowa została wzmiankowana $\mathrm{w}$ dokumencie księcia opolskiego jako miasto posiadające prawo niemieckie wraz z wyodrębnionym terytorium. Brzmienie nazwisk mieszczan wymienionych w liście świadków tego dokumentu świadczy o tym, że przynajmniej część elity pochodziła z Niemiec lub ze Śląska. O ukształtowaniu się organizmu miejskiego świadczą też nieznacznie późniejsze wzmianki o granicach terytorium miejskiego, oznaczonego specjalnie usypanymi kopcami (1382), o rajcach (1385) oraz o wójcie sądowym tego miasta (1388); o uczestniczeniu Częstochowy w zawartym w 1384 roku porozumieniu 22 miast $\mathrm{z}$ terenów będących pod władzą księcia opolskiego ${ }^{22}$.

Przypuszczalny moment wydania przywileju lokacyjnego Częstochowy Antoniewicz określił na lata 1356-1377, przy czym dolną granicę stanowiła data wystawienia dokumentu Kazimierza Wielkiego zezwalającego na lokację dwóch wsi w dziedzinie Częstochowa, a górną granicę pierwsza wzmianka o mieście. Historyk słusznie przyjął, że dla doprecyzowania daty kluczowa „jest osoba sprawcy i wystawcy dokumentu lokacyjnego" ${ }^{23}$. Autor teoretycznie wziął pod uwagę czwórkę władców: Kazimierza Wielkiego, Ludwika Węgierskiego, Elżbietę Łokietkównę i Władysława Opolczyka. Andegawena jednak wykluczył bez większych wątpliwości, wskazując na brak w źródłach „najmniejszego śladu zaangażowania Ludwika Węgierskiego w sprawy terytoriów nadanych Opolczykowi" ${ }^{24}$. Nie uwzględnił przy tym znanej już Stefanowi Krakowskiemu wzmianki w dokumencie króla Stefana Batorego o jakimś przywileju dla miasta wydanym przez Ludwika Andegaweńskiego, uznając ją za zupełnie niewiarygodną. Podobny argument, wskazujący na brak „zaangażowania w sprawy Opolczykowego lenna" ${ }^{25}$, pozwolił odrzucić rolę w procesie lokacyjnym Częstochowy regentki królestwa, starszej królowej Elżbiety. Przeciwko założeniu miasta przez Kazimierza Wielkiego miały przemawiać: dwudziestoletni okres wolnizny wyznaczony w dokumencie lokacyjnym dla wsi w dziedzictwie Częstochowy, wykluczający planowanie fundacji miasta $\mathrm{w}$ tym czasie; lokacja miasta na terenie stanowiącym własność prywatną wiązała się z wykupieniem odpowiedniego fragmentu ziemi, ale wymagałoby to zmiany intencji wyrażonych $\mathrm{w}$ dokumencie wydanym dla

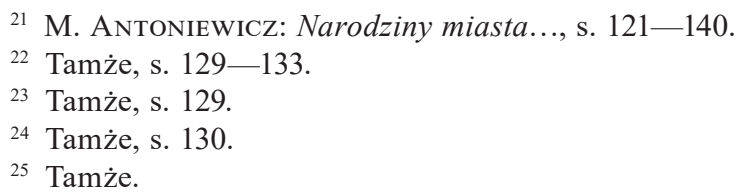


dziedziców wsi Częstochowy. Takie podstawy dawałoby przede wszystkim stworzenie nowego potencjału demograficznego na tym terenie, co - zdaniem Antoniewicza, powołującego się na wysokość świadczonego z parafii częstochowskiej świętopietrza - nie nastąpiło.

Wskazując na lokację Przyrowa, formalnie wszczętą w 1369 roku, historyk podkreślił, że jest to jedyna pewna fundacja miasta dokonana przez Kazimierza Wielkiego na obszarze olsztyńskiego dystryktu zamkowego. Cały wywód dotyczący osoby ostatniego Piasta na polskim tronie jako potencjalnego inicjatora założenia miasta Częstochowy Antoniewicz podsumował retorycznym pytaniem: „Czy możliwe, iżby Kazimierz Wielki podjął w tym samym czasie decyzję o lokacji dwóch miast $\mathrm{w}$ szczególnie słabo zaludnionym regionie Małopolski?"'26.

Po przedstawieniu argumentacji wykluczającej królów Polski jako prawdopodobnych założycieli miasta badacz wskazał na przesłanki przemawiające za Opolczykiem jako inicjatorem lokacji: książę realizował pełny zakres uprawnień monarszych na obszarze lenna - mógł lokować i lokował na jego terenie nowe osady; źródła milczą o jakiejkolwiek ingerencji królów Polski w latach 1370 - $1391 \mathrm{w}$ sprawy dotyczące jego lenna; książę opolski przeprowadzał fundacje miejskie jako namiestnik Rusi oraz dokonał pojedynczych lokacji na innych podległych mu obszarach. W kolejnym argumencie - opartym na przesłance o rzekomym podziale olsztyńskiego dystryktu zamkowego i oddaniu go Opolczykowi tylko w części, bez Przyrowa - historyk wskazywał na zaistnienie po 1370 roku nowej konfiguracji granic, w której miejsce przeprawy przez Wartę stawało się szczególnie dogodne do założenia komory celnej. Ponadto Antoniewicz doszukiwał się w lokacji Częstochowy analogii związanej z założeniem Żarek, które jego zdaniem również należy łączyć $\mathrm{z}$ osobą opolskiego księcia. W tej ostatniej kwestii historyk pozostał przy swoim pierwotnym stanowisku, które zostało podane w wątpliwość w recenzjach i artykułach polemicznych wskazujących na bardzo małe prawdopodobieństwo inicjatywy Opolczyka w tworzeniu Żarek (o czym szerzej w dalszej części).

Brak informacji o dokumencie lokacyjnym Częstochowy zdaniem Antoniewicza mógł wynikać z celowego ignorowania Władysława Opolczyka przez kancelarię królewską. Najmocniej zdaje się brzmieć argument, przejęty od Mariana Haisiga, o symbolice wyobrażonej na najstarszej pieczęci miejskiej: motyw orła i lwa, niewątpliwie nawiązującej do symboliki heraldycznej Władysława Opolczyka jako księcia opolskiego i pana Rusi ${ }^{27}$.

M. Antoniewicz kwestionował z kolei przesłanki, które zdają się przeczyć możliwości dokonania lokacji Częstochowy przez księcia opolskiego. Argument, że okres pomiędzy pierwszą wzmianką o mieście a objęciem tego terenu

\footnotetext{
26 Tamże, s. $133-135$, cyt.: s. 135.

27 Tamże, s. 135-137; M. Antoniewicz: Heraldyka Częstochowy..., s. 538-549.
} 
przez Opolczyka (6 i pół roku) jest zbyt krótki do przeprowadzenia lokacji na „surowym korzeniu”, podważył, podając przykłady inicjatyw Kazimierza Wielkiego, gdzie okres pomiędzy lokacją ośrodka miejskiego a pierwszą o nim informacją źródłową był podobny - 5-6 lat (Lanckorona, Nowy Sącz). Wobec faktu funkcjonowania miasta w 1377 roku Antoniewicz dowodził, że wzmianka nie oznacza zamknięcia procesu urządzania miasta, więc mogło ono być wówczas w początkowej fazie rozwoju. Odnosząc się do rzadkiego wezwania tamtejszej świątyni — św. Zygmunta, pomimo wiedzy, że święty ten był bliski Kazimierzowi Wielkiemu, stwierdził jednak: ,[...] któż bardziej predestynowany był do propagowania dynastycznego kultu Luksemburgów, niźli Władysław Opolczyk?", nie mając żadnych ku temu przesłanek źródłowych $^{28}$. W konkluzji badacz, opierając się na itinerarium księcia, za „najbardziej prawdopodobny moment regulacji praw miejskich Częstochowy" uznał 1. poł. 1373 roku, kiedy to poświadczony jest najdłuższy pobyt Opolczyka na terenie lenna wieluńskiego ${ }^{29}$.

Podsumowując argumentację Antoniewicza - główną przesłanką, na której opiera się cała konstrukcja, jest najstarsza wzmianka o mieście Częstochowie właśnie za rządów księcia opolskiego. Jest to zatem wniosek wywiedziony z milczenia źródeł. Historyk ten, przedstawiając warunki, które poprzedziły lokację miasta Częstochowy, sam jednak podkreślił, że sieć osadnicza gęstniała w dobie Kazimierza Wielkiego, a procesy urbanizacyjne w północno-wschodniej Małopolsce najintensywniej przebiegały w połowie XIV wieku ${ }^{30}$. Dostrzegł też, że w okolicy Częstochowy w tym czasie przeprowadzono reorganizację na prawie niemieckim całego zespołu osad ${ }^{31}$.

Zdecydowanie odmienne stanowisko od tez M. Antoniewicza przedstawił w kolejnych, opublikowanych już po wydaniu monografii miasta, tekstach Jacek Laberschek. W szczególności w artykule z 2002 roku historyk ten odniósł się krytycznie do koncepcji Antoniewicza i w zdecydowany sposób opowiedział się za Kazimierzowską lokacją miasta Częstochowy ${ }^{32}$. Przede wszystkim powątpiewał, czy lata 1373 - 1377, kiedy książę opolski mógłby lokować miasto, były okresem wystarczającym na utworzenie ośrodka w pełni zorganizowanego, zwłaszcza że władca ten do 1372 roku mocno zaangażowany był w sprawy Królestwa Węgier (sprawując tam urząd palatyna) i w tym czasie

${ }_{28}$ M. Antoniewicz: Narodziny miasta..., s. 136-137. Warto zauważyć, że w tej samej monografii Częstochowy Jerzy Żmudziński, autor rozdziału dotyczącego sztuki, stwierdził: „[...] charakterystyczne wezwanie świątyni może (ale nie musi) przemawiać za ostatnimi latami panowania Kazimierza Wielkiego jako czasem powstania świątyni” - J. ŻMudziŃski: Budownictwo i sztuka w Częstochowie do połowy XVII wieku. W: Częstochowa. Dzieje miasta i Klasztoru..., s. 283.

${ }^{29}$ M. Antoniewicz: Narodziny miasta..., s. 137-138.

30 Tamże, s. 127.

31 Tamże, s. 123.

32 J. LABERSCHeK: Częstochowski zespót osadniczy..., s. 8-11. 
był nieobecny w Polsce. Szczególną trudność stanowiło stworzenie przeprawy przez Wartę oraz zmeliorowanie trudnych, podmokłych i zalesionych terenów na obu brzegach tej rzeki, czego nie dało się przeprowadzić w krótkim czasie. Zdaniem Laberscheka lokacja Częstochowy odbywała się na „surowym korzeniu", a warunki, w których przyszło zakładać ten ośrodek, były bardzo trudne, stąd nie może być mowy o okresie wolnizny mniejszym niż 20 lat. Według niego skoro więc miasto zostało poświadczone w 1377 roku, to jego lokacja nastąpiła w podobnym czasie co lokacja rycerskiej wsi o tej nazwie (1356). Przy tym Laberschek zdecydowanie oddziela proces lokacyjny miasta od procesu lokacyjnego wsi, który został przeprowadzony na gruntach królewskich, niezależnie od wsi rycerskich. Krakowski historyk przypuszcza, że właśnie lokacja miasta na lewym brzegu Warty, podjęta ok. 1350 roku, mogła stanowić przesłankę dla dziedziców wsi do zreorganizowania swoich dóbr w podobny sposób, stąd ich starania o królewski dokument. Hipotezie Antoniewicza o możliwości ignorowania dokumentu Opolczyka dla Częstochowy przez kancelarię królewską Laberschek przeciwstawił przypadki kilku miast małopolskich, które choć miały dawniejsze przywileje prawa niemieckiego, to w dokumentach Władysława Jagiełły nic o nich nie wspominano (m.in. Kazimierz, Biecz, Nowy Sącz). Badacz ten uznał też, że symbolika herbu przedstawionego na najstarszej pieczęci miejskiej, nawiązująca niewątpliwie do Władysława Opolczyka, „może co najwyżej stanowić świadectwo sprawowania przezeń pełni władzy nad miastem i osobistego wkładu w dokończenie procesu lokacyjnego, a zwłaszcza działań na rzecz samorządu miejskiego, ukształtowania się pieczęci miejskiej”. W konkluzji autor stwierdził, że „w latach 1373-1376 książę dokończył dzieło budowy miasta, rozpoczęte przed 1370 r." 33 .

W artykule z 2004 roku $^{34}$ dotyczącym wójtostwa częstochowskiego J. Laberschek ponownie podał $\mathrm{w}$ wątpliwość możliwość przeprowadzenia przez Opolczyka lokacji Częstochowy na „surowym korzeniu”, a oprócz wcześniej sformułowanych argumentów wskazał ponadto, że już w 1381 roku pola uprawiane przez mieszczan były nowiznami i podlegały obowiązkowi świadczeń na rzecz Kościoła. Jego zdaniem role te były już po trwającym kilkanaście lat okresie zwolnienia od świadczeń, co wskazuje, że założenie miasta było raczej dziełem Kazimierza Wielkiego. Jak dowodził historyk, „lokacja miasta była niewątpliwie elementem i ogniwem królewskiego planu skolonizowania w krótkim czasie północno-zachodniego fragmentu ziemi krakowskiej i przeprowadzenia ważnego szlaku drożnego z Krakowa do Wielkopolski i na Śląsk z ominięciem klasztornego Mstowa" ${ }^{35}$. Autor podkreślił, że Kazimierz Wielki

33 Tamże, cyt.: s. 11.

34 J. LABERSCHeK: Wójtostwo częstochowskie w czasach piastowskich i jagiellońskich. „Almanach Częstochowy” 2004, s. 7-8.

${ }_{35}$ Tamże, s. 7. 
przeniósł na prawo niemieckie kilka wsi w tym rejonie i zapewne też właśnie on zorganizował przeprawę przez Wartę ${ }^{36}$.

Osobną sprawą, choć związaną z kwestią powstania miasta, są różnice interpretacyjne między obu historykami (Antoniewiczem i Laberschekiem) w odniesieniu do dokumentu Kazimierza Wielkiego z 1356 roku, dotyczącego zgody wydanej braciom Leonardowi i Kanimirowi na lokację na prawie niemieckim dwóch wsi: Częstochowy i innej w ich dziedzinie Częstochowa nad rzeką Rybną. W pierwszym wypadku nie ma wątpliwości, że chodzi o wieś, która od 1382 roku stała się własnością klasztoru Paulinów, zwaną od XV wieku Częstochówka. Drugą z tych wsi, jak już wspomniano, Antoniewicz hipotetycznie lokalizował nad Wartą lub nad ciekiem wodnym wpadającym do Warty i brał pod uwagę, że mogła ona stać się bezpośrednim zapleczem dla założenia miasta. J. Laberschek z kolei, podobnie jak ks. J. Fijałek i Z. Leszczyńska-Skrętowa, identyfikował ją z Kawodrzą położoną nad rzeką Stradomką, lewym dopływem Warty ${ }^{37}$.

Ostatnie słowo w dyskusji obaj badacze - Marceli Antoniewicz i Jacek Laberschek - wypowiedzieli w materiałach stanowiących pokłosie konferencji jubileuszowych zorganizowanych w Częstochowie i Krakowie. Pierwszy z historyków stwierdził, że „mimo odmiennych opinii nadal podtrzymujemy hipotezę, że właśnie Opolczykowi prawa miejskie zawdzięczają Częstochowa i Żarki" "38, kwitując w przypisie polemiczny głos Jacka Laberscheka wiążący obie lokacje z królem Kazimierzem Wielkiem krótkim stwierdzeniem: „[...] wiele wysuwanych przy tym argumentów, niepopartych żadnym źródłem, wciąż pozostaje raczej głosem w dyskusji, niż przybliża domniemane fakty historyczne" 39 . Przy tym nie odniósł się ten badacz do żadnego z argumentów Laberscheka ${ }^{40}$. Inaczej krakowski historyk, który choć również pozostał przy swoim poglądzie, to jednak nie tylko uwzględnił argumenty Antoniewicza, ale bardzo szczegółowo je skomentował. W ostatnim artykule z 2013 roku $^{41}$, po-

36 Tamże, s. 8.

37 J. LABERSCHEK: Nowe spojrzenie na początki miasta Częstochowy..., s. 11-12; TENŻE: Nowe spojrzenie na początki Czestochowy..., s. 21; TenżE: Częstochowski zespół osadniczy..., s. 36; TenżE: Wójtostwo częstochowskie..., s. 8. Interpretację tę przyjęto również w wydawnictwie: Nazwy miejscowe Polski. Historia. Pochodzenie. Zmiany. Red. K. Rymut. T. 4: J-Kn. Kraków 2001, s. 384 (hasło Kawodrza autorstwa K. RYMUTA), podając informację z dokumentu z 1356 r. o zezwoleniu na lokację wsi jako najstarszą wzmiankę o Kawodrzy.

38 M. Antoniewicz: Podstawy i zakres władzy księcia Władysława II opolskiego w ziemi wieluńskiej oraz północno-zachodniej Małopolsce. W: Książę Władysław Opolczyk. Fundator klasztoru Paulinów na Jasnej Górze w Czestochowie. Red. M. Antoniewicz, J. ZBUDNIEWEK. Warszawa 2007, s. 241.

39 Tamże.

40 Tamże.

41 J. LABERSCHEK: Na pograniczu krakowsko-opolskim. Czestochowa pod rzadami Władysława Opolczyka. W: Bunt wójta Alberta. Kraków i Opole we wzajemnych związkach w XIV wieku. Red. J. Rajman. Kraków 2013, s. 162. 
święconym po części powstaniu Częstochowy, autor ponownie stwierdził, że czas przeznaczony na wzniesienie miasta od podstaw w bardzo trudnych warunkach nie mógł być zbyt krótki. Dlatego nie jest możliwe, aby Częstochowa mogła się ukształtować w latach 1373-1376, a najpóźniej w 1381 roku, skoro wówczas już oddawano z miasta świadczenia na rzecz Kościoła, czego dowodzi dokument z 1384 roku, rejestrujący spór biskupów krakowskich Zawiszy z Kurozwęk i Jana Radlicy z klasztorem mstowskim o dziesięciny z nowizn miasta Częstochowy ${ }^{42}$. Długotrwałość procesu lokacji i zakończenie okresu wolnizny co najmniej na początku lat 80 . XIV wieku zdaniem Laberscheka poświadczają, że to Kazimierz Wielki dokonał fundacji miasta Częstochowy. Oprócz tych argumentów historyk ten wskazał jeszcze na wezwanie tamtejszego kościoła, które można wiązać z fundatorem świątyni. Krzewicielem kultu św. Zygmunta w Polsce był bowiem Kazimierz Wielki, natomiast nie wiemy o zainteresowaniu księcia opolskiego tym świętym ${ }^{43}$. Ważne znaczenie ma tu też sam fakt powstania kościoła w mieście już w 1382 roku, co oznaczałoby - gdyby uznać za fundatora Opolczyka — że zbudowano go w niespełna 12 lat. Bardziej prawdopodobna więc wydaje się tu osoba Kazimierza Wielkiego. Laberschek uznał zatem, że dokument lokacyjny miasta został wystawiony w latach 1357-1361, a najpewniej przed 1362 rokiem $^{44}$.

W później opublikowanej pracy pogląd M. Antoniewicza przyjął Jerzy Sperka, autor biografii Władysława Opolczyka, uznając księcia za fundatora miasta Częstochowy ${ }^{45}$. Z kolei opinię J. Laberscheka o Kazimierzowskiej lokacji podjęli ks. Tadeusz $\operatorname{Kos}^{46}$ oraz piszący te słowa ${ }^{47}$.

Niestety badania archeologiczne nie przyniosły efektów, które mogłyby doprecyzować lokację Częstochowy ${ }^{48}$. Po stronie historyków pozostaje więc

42 Tamże.

43 Argument dotyczący patrocinium parafii częstochowskiej, jako przesłanki wskazującej na Kazimierza Wielkiego jako fundatora tej świątyni, został podniesiony także w monografii starostwa olsztyńskiego (K. NabiaŁeK: Starostwo olsztyńskie..., s. 86).

44 J. LABERSCHEK: Na pograniczu krakowsko-opolskim..., s. 159-161.

45 J. SPerka: Władystaw ksiązę opolski, wieluński, kujawski, dobrzyński, pan Rusi, palatyn Wegier i namiestnik Polski (1326/1330_8 lub 18 maja 1401). Kraków 2012, s. 315-317.

46 T. Kos: Fundacja klasztoru jasnogórskiego $w$ świetle nowej interpretacji źródet. Kraków 2002, s. 15.

47 K. NABiAleK: Starostwo olsztyńskie..., s. 80-86.

48 Ostatnio podsumowała wyniki badań archeologicznych na Starym Rynku w Częstochowie Iwona Młodkowska-Przepiórowska. Najstarsze zabytki, jakie udało się odnaleźć, pochodzą z XV w., brak zaś śladów po architekturze średniowiecznej. Relikty zabudowy drewnianej z terenu rynku są w trakcie odrębnego opracowania i dopiero po wykonaniu dodatkowych badań specjalistycznych będzie możliwe ich datowanie (I. MŁoDKowskA-PrzePIÓRowskA: Wyniki archeologicznych badań wykopaliskowych na Starym Rynku w Częstochowie (stanowisko 49), województwo śląskie. W: Badania archeologiczne na Górnym Śląsku i ziemiach pogranicznych w latach 2011-2012. Katowice 2014, s. 183-194; TAż: Ratusz w Starej Częstochowie nad Warta w świetle badań archeologicznych. „Rocznik Muzeum Częstochowskiego” 2018, T. 17, 
zadanie wyjaśnienia genezy miasta poprzez ponowną analizę zachowanych źródeł i nową ich interpretację.

III. Po przytoczeniu stanowiska badaczy, a zwłaszcza poglądów dwóch historyków - Antoniewicza i Laberscheka, pora na przedstawienie własnej propozycji rekonstrukcji przebiegu procesu lokacyjnego miasta Częstochowy nad Wartą. Nie chcąc powtarzać już wcześniej omówionych argumentów, w tym miejscu chciałbym skupić się na ewentualnych dodatkowych przesłankach i spostrzeżeniach oraz odnieść się do tych hipotez, które w moim przekonaniu należy zakwestionować.

Zarówno na podstawie kontekstu osadniczego, jak i samego przebiegu formowania się miasta jest moim zdaniem widoczne zaplanowanie i zrealizowanie tego przedsięwzięcia przez Kazimierza Wielkiego. Lokacja miasta Częstochowy wpisuje się w szerszą akcję kolonizacji północnej Małopolski, podjętą przez tego króla. Wzmożenie akcji osadniczej, a co ważniejsze — kolonizacji na prawie niemieckim, jest widoczne w okolicach Częstochowy w latach 50 . i 60. XIV wieku. Z zachowanych źródeł wiadomo, że w krótkim czasie na terenie olsztyńskiego okręgu zamkowego przynajmniej kilka osad uzyskało prawo niemieckie. W tym czasie dokonano lokacji wsi: Rudniki (1349), Siedlec (1354), Częstochowa oraz być może drugiej wsi w tej dziedzinie (1356), Wyczerpy (1356), Krasawa (1364), Rększowice (1369) ${ }^{49}$. Bardzo możliwe, że za Kazimierza Wielkiego lokowana została też wieś Konopiska (w 1383 roku wzmiankowany sołtys tej wsi). Jest prawdopodobne, że i przeniesienie na prawo niemieckie wsi Wierzchowisko (w 1398 roku poświadczony sołtys) oraz Mirów (stara osada, wzmiankowana od 1220 roku, choć sołectwo tam poświadczone późno - dopiero w latach 1470-1480) nastąpiło jeszcze przed 1370 rokiem $^{50}$. Nie ma zatem wątpliwości, że ostatni Piast rozpoczął kolonizację na prawie niemieckim osad na obu brzegach Warty. Nie sposób zgodzić się więc z M. Antoniewiczem, że wieś Siedlec z parafii mstowskiej, położona na prawym brzegu Warty, leżała na trakcie z Krakowa do Wielkopolski. Można raczej przypuszczać, że nadanie prawa niemieckiego Siedlcowi i być może wsi Mirów towarzyszyło procesowi tworzenia przeprawy przez Wartę, w miejscu, gdzie powstać miało nowe miasto. Kluczowym bowiem momentem dla właściwego skolonizowania tej części ziemi krakowskiej było stworzenie

s. 43-76). Jedyne relikty budynków w Częstochowie, które w przybliżeniu można datować na XIV i XV w., odkryto w podziemiach kościoła św. Zygmunta. Jednak i w wypadku tych obiektów nie ma mowy o precyzyjnym ich datowaniu (R. MAReK, M. WoJcieszak, J. WojcieSZAK: Wyniki badań archeologicznych na terenie parafii pw. św. Zygmunta w Częstochowie, województwo śląsie. W: Badania archeologiczne..., s. 195-205).

49 AGAD, MK, sygn. 45, s. 372-373; ASK, dz. XLVI, sygn. 42, k. 70, 92-92v; Lustracja województwa krakowskiego 1564. Wyd. J. MAŁECKI. Cz. 2. Kraków 1964, s. 26, 30; ZDM, Cz. 4, nr 977, 1004.

${ }^{50}$ J. LaberscheK: Konopiska. W: SHGKr, Cz. 2, s. 750; Tenże: Mirów [parafia Mstów]. W: SHGKr, Cz. 4, s. 531-534. 
nowego ciągu komunikacyjnego, czyli zbudowanie drogi, która łączyła zamek Olsztyn, usytuowany po prawej stronie Warty, z terenem położonym na lewym brzegu tej rzeki. To jednak wymagało, jak wielokrotnie podkreślał J. Laberschek, zorganizowania przeprawy przez Wartę, która na tym odcinku tworzyła rozlewiska. Jak trudny był to teren, świadczą dobitnie informacje z XVI wieku, z których wynika, że przeprawa przez tę rzekę pod Częstochową miała szerokość ok. $500 \mathrm{~m}$ (5 stajań) i składała się z sześciu mostów ${ }^{51}$. Dowodzi to istnienia jeszcze w owym czasie licznych odgałęzień tej rzeki. Należy uznać, że przed zainicjowaniem tam osadnictwa warunki naturalne były jeszcze trudniejsze. Dlatego właśnie wspomniany krakowski mediewista niewątpliwie ma rację, widząc w kwestii organizacji przeprawy przez Wartę kluczowe przedsięwzięcie towarzyszące lokacji miasta. O ścisłym związku budowy mostów na Warcie z lokacją miasta świadczy obszar należący do Częstochowy, który, jak dobrze wiemy z opisu jego granic z XVI wieku, obejmował tereny na obu brzegach Warty ${ }^{52}$. Uwarunkowania naturalne powodowały, że zarówno budowa przeprawy, jak i organizacja osady były kosztownymi działaniami. Wskazane było zatem połączenie obu przedsięwzięć. Była to więc klasyczna lokacja na „surowym korzeniu”, która musiała zostać dobrze zaplanowana i przewidziana na dłuższy czas.

Szeroko zakrojona kolonizacja wiejska wskazuje na realizację przemyślanego planu, którego zwieńczeniem była lokacja miasta. Znalazł tu zastosowanie model osadniczy, określany w literaturze jako Stadt-Land-Kolonisation, stosowany głównie na terenie Niemiec, polegający na jednoczesnym zakładaniu grupy wsi oraz miasta, jako centralnego dla nich ośrodka gospodarczo-ustrojowego ${ }^{53}$. Realizacja tego typu modelu osadniczego, zwłaszcza w terenie słabo zasiedlonym, musiała trwać dość długo, czyli w warunkach polskich ok. 20 lat. Dlatego nie sposób przyjąć, że książę Władysław Opolczyk miał możliwość przeprowadzenia tego procesu w ciągu zaledwie 4-5 lat. Podjęcie akcji osadniczej na tym obszarze wymagało kilku lat na jej przygotowanie,

${ }^{51}$ Lustracja cet i myt małopolskich z 1565 roku. Wyd. B. WyrozUMSKA, przy współpracy M. Starzyńskiego, indeksy oprac. P. Wiencierz. Kraków 2019, s. 14; Lustracja dróg województwa krakowskiego z roku 1570. Wyd. B. WyrozumsKA. Wrocław 1971, s. 63.

${ }^{52}$ Szczegółowa rekonstrukcja granic miasta Częstochowy, oparta na źródłach z XIVXVII w., potwierdza, że miasto posiadało tereny po obu stronach Warty, od Błeszna po Mirów (K. Nabialek: Starostwo olsztyńskie..., s. 143-158).

${ }^{53}$ S. Gawlas: O ksztalt zjednoczonego Królestwa. Niemieckie władztwo terytorialne a geneza spoteczno-ustrojowej odrębności Polski. Wyd. 2. Warszawa 2000, s. 62-64; TenżE: Polska Kazimierza Wielkiego a inne monarchie Europy Środkowej-możliwości i granice modernizacji władzy. W: Modernizacja struktur władzy w warunkach opóźnienia. Europa Środkowa $i$ Wschodnia na przełomie średniowiecza i czasów nowożytnych. Red. M. DyGo, S. Gawlas, H. Grala. Warszawa 1999, s. 27-28; S. Gawlas: Uwagi o polityce miejskiej Kazimierza Wielkiego. W: Aetas media, aetas moderna. Studia ofiarowane profesorowi Henrykowi Samsonowiczowi w siedemdziesiata rocznice urodzin. Warszawa 2000, s. 25-41. 
a następnie ok. 20 dalszych na jej wykonanie. Zaplanowanie tego procesu, biorąc pod uwagę poświadczone działania lokacyjne wobec osad wiejskich, można przypisać tylko Kazimierzowi Wielkiemu.

Kolonizację terenu w okolicach Częstochowy, w tym lokację miasta, trzeba umieścić w szerszym kontekście i związać z planową, szeroką akcją osadniczo-modernizacyjną północnej Małopolski. Wiadomo, że przed 1341 rokiem utworzony został okręg (districtus) zamkowy olsztyński, który swym zasięgiem obejmował również teren Częstochowy. O tym, że Warta ze swoimi rozlewiskami stanowiła w okolicach Mstowa i Częstochowy istotną przeszkodę, a zarazem granicę tychże obszarów, świadczy zasięg okręgów parafialnych. Osady położone na prawym brzegu tej rzeki wchodziły w skład parafii Mstów, wsie na lewym jej brzegu należały zaś do parafii Częstochowa. Odnosi się to do osad położonych nieopodal (zarówno na północ i północny wschód, jak i na południe i południowy wschód) oraz do tych bardziej oddalonych, z których najstarsze były zapewne wsie Rększowice oraz Konopiska. Ta zasada jest widoczna w odniesieniu do wsi Mirów, która będąc własnością królewską, znajdowała się w parafii Mstów. W 1. poł. XIV wieku nie było bezpośredniej, krótkiej drogi łączącej zamek Olsztyn z Częstochową. Przeszkodą była bowiem Warta. Aby dojechać do Częstochowy czy Wyczerp, a najpewniej też do Rększowic położonych najdalej na południowy zachód, przy granicy z księstwem opolskim, trzeba było jechać przez Mstów, gdzie znajdowała się przeprawa przez Wartę. Co więcej, również dojazd z Krakowa do Olsztyna był utrudniony i odbywał się trasą nieco okrężną — przez Lelów. W zjednoczonym państwie istniała potrzeba stworzenia krótszej drogi łączącej stolicę - Kraków - z Polską centralną i Wielkopolską. Nowy trakt publiczny, jak widać to na podstawie źródeł z XV wieku, prowadził od Olkusza lub Skały przez miasta: Ogrodzieniec, Kromołów, Włodowice, Żarki, zamek Olsztyn, Częstochowę, Kłobuck, Krzepice. Dodajmy, że dawny trakt z Krakowa przez Lelów z chwilą powstania przeprawy przez Wartę w Częstochowie nie prowadził już przez Mstów, lecz kierował się do zamku Olsztyn, koło którego łączył się z nową drogą wiodącą z południa, od Żarek ${ }^{54}$.

Genezę większości wymienionych miast wiąże się z pewną lub hipotetyczną inicjatywą Kazimierza Wielkiego. Ostatniemu koronowanemu Piastowi niewątpliwie zawdzięczają prawo miejskie Krzepice (lokacja w 1364 roku). Ten sam król dokonał translacji Kłobucka i Lelowa ${ }^{55}$. Zdaniem F. Kiryka najpraw-

${ }^{54}$ K. Nabialek: Dzieje miasta Olsztynek koło Częstochowy od założenia do połowy XVII wieku. W: ZNUJ, Nr 1256. Prace historyczne, z. 129. Kraków 2002, s. 81.

55 J. LABERSCHeK: W czasach piastowskich i jagiellońskich. W: Kłobuck. Dzieje miasta i gminy (do roku 1939). Red. F. KIRYK. Kraków 1998, s. 90-105; F. SiKora przy współpracy J. LaberscheKa: Krzepice - miasto. W: SHGKr, Cz. 3, s. 204-210; J. LAberscheK: Lelów miasto. W: SHGKr, Cz. 3, s. 496-497; TEnŻE: Dzieje średniowiecznego Lelowa. Lelów 2018, s. $34-36,48-51$. 
dopodobniej Kazimierzowi Wielkiemu powinno się przypisać również założenie Włodowic i Ogrodzieńca, choć pierwsze wzmianki o nich jako miastach sięgają już początku panowania Władysława Jagiełły. Z dużym prawdopodobieństwem z królewską akcją urbanizacyjną wolno łączyć powstanie szlacheckiego miasta Kromołowa, którego wójt sądowy jest poświadczony w 1388 roku, co pośrednio oznacza, że jakiś czas przed tą datą doszło tam do lokacji na prawie niemieckim ${ }^{56}$. Nawet jeżeli nie wszystkie $\mathrm{z}$ wymienionych miast powstały za panowania ostatniego koronowanego Piasta, to i tak należałoby wiązać ich założenie z wytyczeniem nowej drogi publicznej. Trakt krakowsko-wielkopolsko-śląski był tu niewątpliwym czynnikiem miastotwórczym. Dodajmy, że w północnej Małopolsce Kazimierz Wielki przeprowadził lokację także innych miast: Będzina, Przyrowa (o czym dalej), Szczekocin oraz, jak przypuszczam, Mrzygłodu ${ }^{57}$. Liczne są też osady wiejskie, które monarcha ten przeniósł na prawo niemieckie ${ }^{58}$.

Odrębnego omówienia wymaga sprawa założenia miasta Żarki. Wydawać by się mogło, że temat ten został już dość solidnie przedyskutowany naukowo i prawdopodobieństwo związku genezy tego miasta z osobą Władysława Opolczyka jest właściwie niewielkie, a w zasadzie wykluczone. Wprawdzie w literaturze zdania na temat powstania Żarek są podzielone ${ }^{59}$, ale w grun-

${ }^{56}$ F. KIRYK: Z dziejów urbanizacji Wyżyny Krakowsko-Częstochowskiej w średniowieczu. W: Zróżnicowanie i przemiany środowiska przyrodniczo-kulturowego Wyżyny Krakowsko-Częstochowskiej. Red. J. Partyka. T. 2: Kultura. Ojców 2004, s. 34-41; J. LaberscheK: Kromolów. W: SHGKr, Cz. 3, s. 144, 148.

57 J. Sperka: Dzieje Będzina w XIV-XV w. W: Będzin 1358-2008. T. 2: Od pradziejów do rozbiorów. Red. J. Sperka. Będzin 2008, s. 124-125; J. LABERSCheK: Początki i rozwój miasta Szczekociny do końca XV wieku. Uwagi do genealogii Szczekockich herbu Odroważ. W: Patientia et tempus. Ksiega jubileuszowa dedykowana doktorowi Marianowi Korneckiemu. Red. O. Dyba, S. KoŁodziejski, R. Marcinek. Kraków 1999, s. 106-108; D. Lisowicz: Małe miasta przy granicy śląsko-małopolskiej w XIV w. Geneza - funkcje - warunki rozwoju. W: Bunt wójta Alberta..., s. 142-153; K. NABIAŁEK: Średniowieczne dzieje miasta Mrzygłód. Przyczynek do kolonizacji północnej Małopolski w późnym średniowieczu. W: „Średniowiecze Polskie i Powszechne". T. 7 (11). Red. J. Sperka, B. Czwojdrak. Katowice 2015, s. 189-205.

58 J. MAStowsKI: Kolonizacja wiejska na prawie niemieckim $w$ województwach sieradzkim, tęczyckim, na Kujawach $i$ w ziemi dobrzyńskiej. Rocz. Hist. 1937, T. 13, s. 213-223; J. LuCiŃsKi: Lokacje wsi i miast monarszych w Małopolsce do 1385 r. CP-H 1965, T. 17, nr 2 , s. 102-113; S. Kuraś, rec.: J. Luciński: Majątki ziemskie panującego w Małopolsce do 1385 roku, Poznań 1967. St. Hist. 1968, T. 11, s. 596; TenżE: Przywileje prawa niemieckiego miast $i$ wsi małopolskich XIV-XV wieku. Wrocław 1971.

${ }^{59} \mathrm{Za}$ księciem Władysławem Opolczykiem jako założycielem Żarek opowiedzieli się: M. Antoniewicz, J. Sperka, a także początkowo J. Laberschek (M. Antoniewicz: Przeszłość Żarek. Powstanie i rozwój miasta na przestrzeni sześciu wieków. Częstochowa 1982, s. 18-21; TENŻE: Niektóre problemy genezy miasta Żarek na tle politycznych dziejów regionu w XIV wieku. W: Szkice do dziejów Żarek. W 600-lecie miasta. Red. H. Rola. Katowice 1984, s. 9-20; M. Antoniewicz: W sprawie genezy miasta Żarki [kilka uwag po artykule J. Laberscheka i recenzji Z. Nogi]. St. Hist. 1987, T. 30, nr 2, s. 315-321; J. SperKA: Wtadysław książe 
cie rzeczy wszystkie argumenty, poza datą najstarszej wzmianki, przemawiają tu za Kazimierzem Wielkim jako autorem inicjatywy lokacyjnej. Po raz pierwszy Żarki jako miasto wzmiankowano w dokumencie z 1382 roku $^{60}$. Już w 1373 roku poświadczony został kościół parafialny w Żarkach, a przy tym z parafii tej świadczono już świętopietrze (w wysokości 2 skojców). Mamy tu więc do czynienia z już ukształtowaną parafią, najpewniej posiadającą kościół parafialny. Wydaje się mało prawdopodobne, czy wręcz niemożliwe, aby jednym z pierwszych wzniesionych budynków w nowo założonym mieście był właśnie kościół. Zresztą nawet zakładając hipotetycznie taką ewentualność, chcąc uznać księcia opolskiego za założyciela miasta, i tak należałoby przyjąć, że proces wznoszenia kościoła oraz formowania się parafii musiałby być błyskawiczny i trwać mniej niż 3 lata. A to jest w zasadzie niemożliwe, zwłaszcza jeśli weźmie się pod uwagę niewielkie zaangażowanie Władysława Opolczyka w sprawy nowo uzyskanego terytorium bezpośrednio po listopadzie 1370 roku. Podkreślić tu należy, że parafia w Żarkach wyodrębniona została z wcześniej istniejącej parafii w Leśniowie. Kościół w Żarkach został zbudowany w odległości zaledwie $1 \mathrm{~km}$ od leśniowskiej świątyni, która nadal pełniła funkcję ośrodka parafii ${ }^{61}$. Nie ma innego racjonalnego powodu wzniesienia $\mathrm{w}$ tak bliskiej odległości dwóch kościołów parafialnych, jak uznanie, że kościół w Żarkach zbudowano dla nowo lokowanego miasta, jako filialny wobec macierzy w Leśniowie ${ }^{62}$.

Fakt istnienia kościoła parafialnego, z którego pleban świadczył świętopietrze w 1373 roku, każe przesunąć jego fundację co najmniej o 10—20 lat wstecz, czyli do lat 50. lub 60. XIV wieku. Potwierdzenie daje tu inny przykład z terenu dystryktu olsztyńskiego i z tego samego dekanatu. W związku z lokacją miasta Przyrowa (o której dalej), która rozpoczęła się na pewno wcześniej niż by to wskazywał kontrakt lokacyjny z marca 1369 roku, wydany przez króla Kazimierza Wielkiego, utworzona została nowa parafia w Komorowie, wydzielona $z$ parafii Podlesie. We wspomnianym już rejestrze świętopietrza parafia wprawdzie została wymieniona, ale wówczas pleban jeszcze

opolski..., s. 315-316). Za lokacją Żarek przez Kazimierza Wielkiego optują: J. Laberschek, Z. Noga, F. Kiryk oraz K. Nabiałek (J. LABersCheK: Początki miasta Żarki i pierwszy wiek jego istnienia. St. Hist. 1986, T. 29, nr 3, s. 329-339; TenŻE: Na pograniczu krakowsko-opolskim..., s. 159; Z. NoGA, rec.: Szkice do dziejów Żarek. W 600-lecie miasta, red. H. Rola. Katowice 1984. St. Hist. 1986, T. 29, nr 3, s. 477; F. KIRYK: Z dziejów urbanizacji Wyżyny Krakowsko-Częstochowskiej..., s. 35; K. Nabialek: Starostwo olsztyńskie..., s. 112; TenżE: Średniowieczne dzieje miasta Mrzygłód..., s. 191-192).

${ }^{60}$ ZDPaul, nr 13.

${ }^{61} \mathrm{~W}$ rejestrach świętopietrza $\mathrm{z}$ lat 1373 -1374 zostały wymienione oba kościoły parafialne - w Leśniowie i w Żarkach, a plebani każdego z nich zapłacili wówczas świętopietrze. Przy tym drugim wyraźnie jednak zaznaczono: de Zari nova fundatio (Liber receptorum et expensarum Petri Stephani 1373-1375. Ed. S. Szczur. In: MPV, T. 9, s. 9, 28-29).

62 Wykazał to J. LaberscheK: Poczatki miasta Żarki..., s. 331. 
dziesięciny papieskiej nie płacił ${ }^{63}$. Oznacza to, że proces formowania się miasta założonego na pewno przez Kazimierza Wielkiego był mniej zaawansowany od procesu rozwoju Żarek. Wniosek jest tu zatem oczywisty. Płatnikami dziesięciny papieskiej, czyli parafianami kościoła w Żarkach, byli z całą pewnością właśnie mieszczanie. A więc musiał się wówczas zakończyć okres ich wolnizny, który w wypadku lokacji na „surowym korzeniu” trwał co najmniej 20 lat. Proces lokacyjny Żarek rozpoczął się zatem w przybliżeniu 2 dekady przed wzmianką w rejestrach świętopietrza, a więc ok. 1350 roku.

Mimo wskazanych argumentów M. Antoniewicz pozostał przy swojej pierwotnej hipotezie, uznając za założyciela Żarek księcia opolskiego ${ }^{64}$. Co więcej, w lokacji Częstochowy historyk doszukuje się analogii związanej z powstaniem Żarek, nawet przy tym nie sygnalizując wątpliwości co do genezy tego miasta podnoszonych przez innych badaczy ${ }^{65}$. Można tu wprawdzie zgodzić się z częstochowskim historykiem, że istnieje podobieństwo okoliczności, w których oba miasta powstały, ale dające właśnie przesłankę do zakwestionowania w tych przedsięwzięciach sprawczej roli Opolczyka. Rozpoczęcie akcji lokacyjnej Żarek przez Kazimierza Wielkiego, o istnieniu którego to miasta informują dopiero źródła z czasów, gdy północną Małopolską władał książę opolski (pierwsze wzmianki: 1373, 1382), przypomina proces formowania się miasta Częstochowy (najstarsza wzmianka: 1377). Oba miasta jako zobowiązane do świadczeń na rzecz monarchy i Kościoła poświadczone są też w zbliżonym czasie (Częstochowa w 1381 i 1382, Żarki w 1382). Wydaje się więc, że okoliczności powstania Żarek dają kolejną silną przesłankę do łączenia lokacji miasta Częstochowy z osobą Kazimierza Wielkiego.

Wracając do sformułowanej wcześniej tezy, lokacje wspomnianych miast - Ogrodzieńca, Kromołowa, Włodowic, Żarek, Częstochowy, Kłobucka, Krzepic, ale i Mrzygłodu (nawet jeżeli nie w każdym wypadku geneza ośrodka nastąpiła jeszcze za panowania ostatniego Piasta) - jak się wydaje, $\mathrm{z}$ jednej strony wiążą się ściśle z wytyczeniem przez Kazimierza Wielkiego nowej drogi łączącej stolicę (Kraków) z centralną i północną częścią zjednoczonego państwa, a z drugiej strony stanowią filary podjętej przez króla szeroko zakrojonej akcji kolonizacyjnej i urbanizacyjnej obszaru nad górną Wartą, poczynając od źródeł tej rzeki.

${ }^{63}$ MPV, T. 9, s. 9, 29: de Conarow fundata de Podlesso (w rejestrach za lata 1373-1374 przy tej nocie brak kwoty i brak czasownika solvit); J. LABERSCHEK: Rozwój sieci parafialnej $w$ dekanacie lelowskim do 1500 r. W: Księga jubileuszu stulecia Diecezji Kieleckiej (18831983). Kielce 1986, s. 241; TenżE: Komorów. W: SHGKr, Cz. 2, s. 729_730.

${ }^{64}$ M. Antoniewicz: Narodziny miasta..., s. 136; TenżE: Podstawy i zakres władzy..., s. 241.

${ }^{65} \mathrm{M}$. Antoniewicz w tekście głównym nic nie wspomina o głosach polemicznych, w przypisie zaś, obok jednego artykułu J. Laberscheka, cytuje wyłącznie prace swojego autorstwa (M. Antoniewicz: Narodziny miasta..., s. 136, przyp. 110). 
Pod koniec życia Kazimierz Wielki z pewnością zainicjował na obszarze olsztyńskiego okręgu zamkowego lokację miasta Przyrów, wydając w 1369 roku kontrakt lokacyjny. Wypada zgodzić się z Anną Berdecką, że proces zakładania tego ośrodka zaczął się wcześniej niż wskazuje data wydania dokumentu ${ }^{66}$. Wspominam tu o powstaniu tego miasta, ponieważ M. Antoniewicz jako jeden z argumentów przeciwko lokacji Częstochowy przez Kazimierza Wielkiego podniósł kwestię zainicjowania założenia Przyrowa, formułując to jako przytoczone już pytanie: czy król podjąłby „w tym samym czasie decyzję o lokacji dwóch miast w szczególnie słabo zaludnionym regionie Małopolski?" ${ }^{67}$. Historyk ten nie zauważył przy tym, że Przyrów nie tylko jest znacznie oddalony od Częstochowy (ok. $30 \mathrm{~km}$ ), ale dodatkowo miał zupełnie inne położenie geograficzno-polityczne, wpisując się w inny ciąg komunikacyjny państwa. Lokacja Przyrowa stanowiła próbę zmeliorowania słabo osiedlonego terenu na pograniczu małopolsko-sieradzkim, przez które przebiegały szlaki komunikacyjne z ziem krakowskiej i sandomierskiej w kierunku Piotrkowa. W kontrakcie lokacyjnym Przyrowa z 1369 roku Kazimierz Wielki sytuował teren, na którym miało powstać miasto między Lelowem a Radomskiem. Odrębność terenu wokół Przyrowa widoczna jest nawet w obrębie starostwa olsztyńskiego nie tylko w późnym średniowieczu, ale również w okresie nowożytnym ${ }^{68}$. Dlatego lokacja tego miasta nie stanowiła żadnej alternatywy dla Częstochowy. Wydaje się, że jest to kolejny dobitny dowód na determinację króla, aby kolonizować obszary dotąd niezasiedlone i niezagospodarowane w północnej Małopolsce. Jeżeli rozpatrywać powstanie Przyrowa w kontekście genezy Częstochowy, to raczej jako przejaw konsekwentnego prowadzenia akcji kolonizacyjnej na terenie dóbr podlegających zamkowi Olsztyn. Reorganizacja zachodniego obszaru tego położonego nad Wartą dystryktu z największą intensywnością odbywała się w latach 50. XIV wieku, przy czym jej kulminacyjnym przedsięwzięciem była lokacja miasta Częstochowy. Decyzja o założeniu Przyrowa świadczy o dużym zaawansowaniu procesu melioracji częstochowskiego skupiska osadniczego i o przeniesieniu w latach 60. XIV wieku ciężaru kolonizacyjnego w kierunku wschodnim.

Z Przyrowem wiąże się jeszcze jedno nieporozumienie, które pojawia się w wywodzie M. Antoniewicza, opartym na dawniejszych ustaleniach w kwestii zasięgu lenna Władysława Opolczyka w ziemi krakowskiej. Otóż nie ma żadnych podstaw do stwierdzenia, że olsztyński dystrykt zamkowy

${ }^{66}$ A. BERDECKA: Lokacje i zagospodarowanie miast królewskich w Małopolsce za Kazimierza Wielkiego (1333-1370). Wrocław 1982, s. 35.

${ }^{67}$ M. Antoniewicz: Narodziny miasta..., s. 135.

68 Szerzej o okolicznościach lokacji Przyrowa oraz o wyodrębnionym w strukturze starostwa olsztyńskiego co najmniej od 1. poł. XV w. kluczu zarębickim, w skład którego wchodziło miasto Przyrów, zob. K. NabiaŁeK: Starostwo olsztyńskie..., s. 79—80, 165-169, $537-538$. 
w 1370 roku został podzielony i książę opolski uzyskał tylko jego część, bez Przyrowa. Takie założenie prowadziło częstochowskiego historyka do przekonania o zaistnieniu po 1370 roku nowej konfiguracji granic, sytuującej Częstochowę $\mathrm{w}$ położeniu peryferyjnym ${ }^{69}$. Badania nad starostwem olsztyńskim przekonują, że granica olsztyńskiego okręgu zamkowego sięgała nawet jeszcze za Przyrów, w głąb ziemi sieradzkiej ${ }^{70}$. Sama zaś refleksja o ważnym usytuowaniu miasta, bardzo dogodnym dla założenia komory celnej, jest słuszna. Inna jednak niż wskazuje Antoniewicz była tego przyczyna. Powodem było wyznaczenie nowej przeprawy przez Wartę, która stanowiła podstawę wytyczenia nowego przebiegu odcinka drogi publicznej z Małopolski do Wielkopolski, a jednocześnie najkrótszego łącznika między centrum starostwa, tj. zamkiem Olsztyn, a podległym mu terenem, położonym — za Wartą — na lewym brzegu tej rzeki. Częstochowska komora celna, co dobrze ilustrują późniejsze źródła (zwłaszcza lustracje dróg i ceł z XVI wieku), stanowiła przy tym podstawę zdobywania środków na utrzymanie zarówno mostów na Warcie (sześciu w latach 1565-1570), jak i fragmentu tego traktu biegnącego przez obszar miasta ${ }^{71}$.

Ważna dla zrekonstruowania sytuacji osadniczej poprzedzającej założenie miasta jest odpowiedź na pytanie o to, jakie były konsekwencje dokumentu Kazimierza Wielkiego z 1356 roku, wydanego dla Leonarda i Kanimira na lokację na prawie niemieckim dwóch wsi w ich dziedzinie Częstochowa jednej na starym miejscu i drugiej na nowym miejscu. Jeżeli chodzi o wieś Częstochowę (późniejszą Częstochówkę), to zgodnie przyjmuje się, że osada ta została zreorganizowana. Warto jednak zauważyć, że w zachowanych źródłach nie ma żadnej wzmianki o funkcjonowaniu instytucji prawa niemieckiego w tej wsi. Z kolei przyznać trzeba rację M. Antoniewiczowi, że wspomniana w dokumencie z 1356 roku, wydanym dla Leonarda i Kanimira, wieś in merica nad rzeką Rybną mogła nigdy nie powstać ${ }^{72}$. Dziedzice wsi otrzymali zgodę od króla na lokację, ale mogli jej nie zrealizować. Jeżeli przyjmiemy, że do realizacji tego aktu lokacyjnego jednak doszło, to wydaje się, że można wskazać na inną wieś, niż to czyniono w dotychczasowej literaturze. Dotąd brano pod uwagę albo nieokreśloną osadę nad Stradomką (S. Krakowski), albo Kawodrzę (ks. J. Fijałek, Z. Leszczyńska-Skrętowa, J. Laberschek), albo wieś nad Wartą, w pobliżu obszaru późniejszego miasta Częstochowy (M. Antoniewicz). Trudno polemizować z hipotezą Antoniewicza, gdyż, zakładając nawet jej trafność, nowa wieś została wchłonięta przez lokowane później miasto, nie pozostawiając po sobie śladu. Za to przeciwko temu, że w 1356 roku oprócz nadania prawa niemieckiego wsi Częstochowie lokowana

\footnotetext{
${ }^{69}$ M. Antoniewicz: Narodziny miasta..., s. 136.

70 K. Nabiatek: Starostwo olsztyńskie..., s. 98-105.

${ }^{71}$ Lustracja cet i myt..., s. 14; Lustracja dróg..., s. 63-64.

72 M. Antoniewicz: Narodziny miasta..., s. 125-126.
} 
została wieś Krowodrza (obecnie Kawodrza), zdaje się przemawiać z jednej strony brak informacji o posiadaniu przez tę wieś prawa niemieckiego (brak wzmianki o sołectwie), a z drugiej — niewiązanie w tradycji klasztornej wsi Krowodrzy z dokumentem z 1356 roku (choć Częstochowę jednoznacznie łączono z Częstochówką).

Po przeanalizowaniu sytuacji osadniczej można postawić hipotezę, że nową osadą założoną w dziedzinie Częstochowy mogła być Grabowa (dziś: Grabówka). Wieś ta po raz pierwszy jest poświadczona w 1385 roku — wówczas została nadana przez księcia opolskiego klasztorowi Paulinów na Jasnej Górze. Osada ta sąsiadowała bezpośrednio z wsią Częstochową. Jej nazwa jest nazwą topograficzną, wskazującą na warunki naturalne, w których powstała. To najbardziej „leśna” nazwa ze wszystkich średniowiecznych osad dzisiejszej Częstochowy ${ }^{73}$. Przypomnijmy, że w dokumencie z 1356 roku jest mowa o zgodzie na założenie wsi in merica, co przyjęło się tłumaczyć na język polski jako „dąbrowa”, choć jest to tylko jedno z możliwych znaczeń tego słowa. Bardziej właściwe jest tu szersze rozumienie: „las”, „gaj”, „,zarośla”, nieokreślające ściśle gatunku drzew, a jedynie może wskazujące na las liściasty ${ }^{74}$. W krajobrazie naturalnym występował typ lasu zwany grądem, który był mieszanym lasem liściastym, złożonym głównie z dębów i grabów. Taką strukturę mógł mieć właśnie las przylegający do dziedziny Częstochowa, a nowo lokowana osada mogła przyjąć nazwę od dominujących tam grabów. Wieś Grabowa w średniowieczu przylegała do rzeki Kocinki, która stanowi prawy dopływ Liswarty, a potwierdzenie wspomnianego cieku wodnego (określonego jako Kaczenka) na terenie tej wsi znajduje się jeszcze w spisie urzędowych nazw z 1972 roku $^{75}$. Dodajmy ponadto, że nazwa rzeki - Kocinka, jest późna i nie notują jej źródła średniowieczne ${ }^{76}$. Natomiast nad tą właśnie rzeką w odległości kilkunastu kilometrów od Grabowej znajduje się wieś Rybna, usytuowana już na terenie ziemi wieluńskiej. Powstaje zatem zasadne pytanie: czy w XIV wieku rzeka

${ }^{73}$ K. Rymut zakwalifikował nazwę Grabowa do nazw wieloznacznych, tj. topograficznych lub dzierżawczych. Wydaje mi się, że ze względu na późną genezę tej osady najbardziej prawdopodobna jest tu ta pierwsza kategoria. Forma zdrobniała „Grabówka” jest z pewnością wtórna i została utworzona po XIV w., jak sądzę, pod wpływem zmiany nazwy sąsiedniej Częstochowy na Częstochówkę. Por. K. Rymut: Nazwy miejscowe pótnocnej części..., s. $56-57,223$.

${ }^{74}$ Słownik łaciny średniowiecznej w Polsce (http://scriptores.pl/elexicon/ [data dostępu: 21.11.2018]) jako pierwsze znaczenie „merica” podaje wprawdzie termin „dąbrowa”, ale już w dalszych znaczeniach uwzględnia ogólne pojęcia lasu, zarośli. W takim szerszym rozumieniu termin ,merica” zdefiniowano jako: „Nemus, silva, atque interdum terrae circumquaque adiacentes", w: Du CANGE et alii: Glossarium mediae et infimae latinitatis. Dostępne w Internecie: http://ducange.enc.sorbonne.fr/MERICA1 [data dostępu: 21.11.2018].

75 Urzędowe nazwy miejscowości i obiektów fizjograficznych. Z. 202: Powiat częstochowski i powiat miejski Częstochowa, województwo katowickie. [Warszawa] 1972, s. 7.

76 J. LABerscheк: Kocinka. W: SHGKr, Cz. 2, s. 691; Stownik historyczno-geograficzny ziemi wieluńskiej w średniowieczu. Oprac. R. Rosin. Warszawa 1963, s. 691. 
zwana później Kocinką, przynajmniej w początkowym biegu, nie mogła nosić nazwy Rybna? Istotny jest również fakt, że wieś Grabowa posiadała prawo niemieckie, czego dowodzi poświadczenie w XV i w XVI wieku sołtysa i sołectwa tamże ${ }^{77}$. Warto podkreślić, że droga biegnąca $\mathrm{z}$ Krakowa w kierunku Wielunia prowadziła przez miasto Częstochowę, Jasną Górę, Częstochowę Starą i właśnie Grabówkę ${ }^{78}$. Można więc powiązać założenie Grabówki z powstaniem nowej drogi z Krakowa.

Ważną przesłanką czy wręcz dowodem wskazującym na zakończenie lokacji i formowania się miasta jest informacja o rozpoczęciu procesu o dziesięciny z nowizn miasta Częstochowy. Nasuwa się tu analogia do omówionego przez Franciszka Sikorę sporu związanego z lokacją Ropczyc o dziesięciny z miasta i wsi. Dziesięciny z ról miasta Ropczyce zostały przyznane biskupowi, a dziesięciny z wsi zachował dotychczasowy posesor, czyli pleban ${ }^{79}$. Dla Częstochowy mamy informację o wszczętym przez biskupa krakowskiego Zawiszę z Kurozwęk sporze z klasztorem Kanoników regularnych na Piasku we Wrocławiu i prepozytem mstowskim o dziesięciny z nowizn należących do tego miasta (super decimis seu novalibus de dicto oppido Czanstochowa), z terenów w jego granicach (infra limites opidi Czanstochowa). Ponieważ konflikt rozpoczął się w czasie urzędowania biskupa Zawiszy z Kurozwęk, to należy go datować na okres między 4 marca 1380 a 12 stycznia 1382 roku, a więc najpewniej na 1381 rok. Zwraca uwagę informacja, że jako strona sporu wymienieni zostali w tekście dokumentu też rustici sive oppidani in Czanstochowa ${ }^{80}$. Rzeczownik rusticus zasadniczo oznacza wieśniaka, mieszkańca wsi ${ }^{81}$. Wydaje mi się, że takie podwójne określenie — wieśniacy i mieszczanie — może wskazywać na to, że w granicach miasta znalazły się i role należące wcześniej do wsi, i te, które później wytyczono dla miasta. Dopuszczalna jest tu zarówno interpretacja, że lokację miasta poprzedziło założenie osady wiejskiej — co proponuje M. Antoniewicz - jak i taka, że do miasta włączono część ról należących wcześniej do innej wsi, np. Częstochowy Starej. Istotne jest nazewnictwo - Częstochowa Stara i Częstochowa Nowa - wskazujące na związek między obiema osadami. Nasuwa się tu analogia do innych podobnych sytuacji osadniczych, a zwłaszcza do omówionej przez F. Sikorę lokacji Ropczyc. Tam obok dawniej istniejącej wsi założona została wieś nowa, którą następnie przekształcono na miasto. Krótko po lokacji pierwotna wieś nazywała się Ropczyce Stare, miasto zaś Ropczyce Nowe. Z czasem wieś zmieniła nazwę na Chechły. F. Sikora, który drobiazgowo omówił proces lokacyjny Ropczyc,

77 J. LABerscheK: Grabówka. W: SHGKr, Cz. 2, s. 38.

${ }^{78}$ Lustracja dróg..., s. 63-64.

79 F. SiKora: Ropczycki zespót osadniczy w średniowieczu. Z badań nad kazimierzowskim modelem osadniczo-urbanizacyjnym. „Teki Krakowskie” 1996, T. 3, s. 77-79.

${ }^{80}$ ZDKK, Cz. 1, nr 88.

${ }^{81}$ Stownik łaciny średniowiecznej w Polsce. T. 8, z. 4. Kraków 2006, kol. 597-598. 
wskazał, że jako miejsce do założenia ośrodka miejskiego przewidziano grupę wsi położonych w sąsiedztwie Ropczyc ${ }^{82}$.

Dokonanie lokacji miejskiej wymagało stworzenia zaplecza dla tego przedsięwzięcia i uporządkowania spraw własnościowych na obszarze przylegającym do fundowanego ośrodka. Trzeba sobie zdać sprawę z tego, co potwierdzają inne procesy lokacyjne, że dla areału nowego miasta określonego w przywileju prawa niemieckiego bardzo trudno było precyzyjnie zaplanować teren, zwłaszcza gdy był on słabo zasiedlony lub gdy była to lokacja na „surowym korzeniu". Dlatego monarcha z reguły przewidywał pewną rezerwę, przeznaczając dla zakładanego ośrodka możliwość zajęcia jeszcze innych osad położonych nieopodal. Widać to choćby na przykładzie wspomnianych Ropczyc czy Piwnicznej koło Sącza ${ }^{83}$. Zapewnienie z kolei możliwości działania na szerszym terenie wymagało uporządkowania sytuacji prawno-własnościowej na całym przewidzianym dla lokacji obszarze. Stosunkowo często król nie był właścicielem wszystkich potrzebnych do założenia miasta gruntów. Nierzadkie były też wypadki zakładania miast na terenach, które monarcha musiał wykupić w całości - np. Bochnia (teren wykupiony od klasztoru Benedyktynek w Staniątkach), Nowy Sącz (teren wykupiony od biskupstwa krakowskiego) czy Proszowice, pierwotnie wieś rycerska, która przed 1358 rokiem drogą nieznanej transakcji (wykup, konfiskata?) znalazła się w rękach Kazimierza Wielkiego ${ }^{84}$. Tak musiało być i w przypadku Częstochowy. Patrząc na późniejszą sytuację osadniczą, z czasów, gdy miasto już istniało, można przyjąć, że naturalnym zapleczem dla miasta były wsie Częstochowa, Krowodrza i zapewne też Grabowa. Władca, który zaplanował lokację, musiał więc zapewnić sobie możliwość skorzystania z tych terenów, z pewnością więc je pozyskał. Podzielam pogląd J. Laberscheka, że wydanie przywileju prawa niemieckiego dla dziedziców Częstochowy w 1356 roku musiało być poprzedzone królewską aktywnością na sąsiednim obszarze. Uważam, podobnie jak krakowski mediewista, że monarcha przed 1356 rokiem rozpoczął budowę przeprawy przez Wartę oraz zasiedlanie obszaru bezpośrednio nad tą rzeką. Inaczej za to niż Laberschek przypuszczam, że Kazimierz Wielki rozpoczął proces osadniczy nie od fundacji miasta, ale od założenia wsi, podobnie jak w wypadku wielu innych lokacji na „surowym korzeniu”. Następnym etapem było zapewne przekształcenie osady wiejskiej w miasto. Właśnie z powodu planu założenia miasta król mógł zachęcić dziedziców wsi Częstochowy do zreorganizowania swojej własności na prawie niemieckim, biorąc pod uwagę możliwość wykorzystania tego do swoich celów. Wspomniani wcześniej rustici, o których role w granicach miasta

${ }^{82}$ F. SiKora: Ropczycki zespót osadniczy..., s. 73-88.

83 K. NabialeK: Młodów. W: SHGKr, Cz. 4, s. 555.

${ }^{84}$ K. KAMIŃSKA: Lokacje miast na prawie magdeburskim na ziemiach polskich do $1370 \mathrm{r}$. (studium historycznoprawne). Toruń 1990, s. 126-127; F. KIRYK: Miasto średniowieczne. W: Proszowice. Zarys dziejów do 1939 roku. Red. F. KinYK. Kraków 2000, s. 47—49. 
Częstochowy toczył się spór, zdają się dowodzić, że przy wytyczaniu obszaru miasta wykorzystano role wiejskie. Otwarte pozostaje pytanie, czy chodziło o teren wsi wcześniej istniejącej (Częstochowa Stara), czy też założonej bezpośrednio przed lokacją nowej osady nad Wartą (Częstochowa Nowa). Z późniejszych źródeł dość dokładnie wiadomo, że terytorium wsi Częstochowy Starej (Częstochówki) znajdowało się na północ oraz na północny wschód i północny zachód od Jasnej Góry. Granica między Częstochówką a miastem Częstochową zaczynała się od drogi z miasta do klasztoru i biegła na północny wschód aż do granicy wsi Kiedrzyn. Od drogi z miasta do klasztoru w kierunku południowym i południowo-zachodnim biegła granica miasta $z$ terenem należącym do kuźnicy. Później zaczynała się granica miasta i wójtostwa częstochowskiego z wsią Krowodrzą (Karwodrza, dziś: Kawodrza). Położenie obu wsi - Częstochowy i Krowodrzy - w naturalny sposób stanowiło potencjalne zaplecze lokacyjne dla formującego się miasta. W nazwie tej drugiej osady zachowała się zresztą informacja o usytuowaniu na jej terenie miejsca uboju zwierząt, niewątpliwie na potrzeby miasta ${ }^{85}$. Z dużym prawdopodobieństwem można uznać, że inicjator lokacji miasta już na etapie wstępnym założył możliwość wykorzystania terenu obu wsi, zwłaszcza Częstochowy, jako potencjalnego obszaru miejskiego. Jeżeli trafna jest moja hipoteza, to również wieś Grabowa stanowiła potencjalny teren do wykorzystania dla miasta. Przynajmniej jedna z osad w 1356 roku była zaś własnością rycerską. Dlatego najpewniej jeszcze przed wystawieniem dokumentu lokacyjnego osoba zakładająca miasto musiała wejść w posiadanie tych wsi.

Skomplikowana struktura własnościowa osad na obszarze przylegającym do miasta Częstochowy od północy, istniejąca na początku XV wieku, jak przypuszczam, mogła być spowodowana zmianami własnościowymi, które zostały przeprowadzone przed lokacją miasta i w jej trakcie. W XV wieku wzmiankowani są szlachcice, którzy dziedziczą część Wyczerp oraz piszą się z Częstochowy. Być może część Częstochowy, która na początku XV wieku znajdowała się w rękach szlacheckich, obejmowała dawne sołectwo w tej wsi. Choć wieś w 1356 roku uzyskała prawo niemieckie, to w późniejszych źródłach sołectwo w tej wsi nie jest wzmiankowane. Być może tu właśnie kryje się klucz do wyjaśnienia zmian sytuacji własnościowej w okolicach Częstochowy w ostatniej ćwierci XIV wieku. W 1356 roku wieś Częstochowa była własnością

${ }^{85}$ Według językoznawców jest to nazwa określająca 'miejsce, w którym zabijano i obdzierano ze skóry krowy'. Wskazano przy tym, że poświadczona w źródłach oboczność Karwodrza/Krowodrza dotyczy słów „krowa” i „karw” (,wół”) — K. Rymut: Nazwy miejscowe pótnocnej części..., s. 70; TenżE: Kawodrza..., s. 384. Podobnie wywodzone jest pochodzenie nazwy podkrakowskiej wsi Krowodrzy, obecnej dzielnicy Krakowa, wzmiankowanej już w 1257 r., por. TenżE: Nazwy miejscowe pótnocnej części..., s. 82; TENŻE: Krowodrza. W: Nazwy miejscowe Polski. Historia. Pochodzenie. Zmiany. Red. K. Rymut. T. 5: Ko-Ky. Kraków 2003, s. $339-340$. 
rycerską, w 1382 roku zaś książęcą. W 1356 roku Wyczerpy były własnością królewską, na początku XV wieku z kolei większość tej wsi znajdowała się w rękach rycerskich. Może król, chcąc wykorzystać część obszaru wsi Częstochowy jako zaplecze dla nowo lokowanego miasta, dokonał transakcji z dotychczasowymi dziedzicami - w zamian za wieś Częstochowę oddał im część wsi Wyczerpy i pozostawił w ich rękach sołectwo w Częstochowie?

Dotąd przyjmowano, że to książę Władysław Opolczyk wykupił od dotychczasowych dziedziców obie wsie (lub ich części), a następnie przekazał je nowo fundowanemu klasztorowi Paulinów na Jasnej Górze. Przeciwko dokonaniu zmian własnościowych przez księcia opolskiego, które miały przygotować ten obszar do lokacji miasta, przemawia przede wszystkim właśnie fakt, że w 1382 roku władca ten nadał klasztorowi Paulinów wieś Częstochowę oraz Krowodrzę, a więc osady stanowiące naturalne zaplecze dla nowo zakładanego miasta. Jaki byłby sens, żeby książę osłabiał zakładany przez siebie organizm miejski? W jakim celu dokonywałby zmian własnościowych, pozyskując wsie rycerskie, by natychmiast pozbyć się ich na rzecz klasztoru ${ }^{86}$ ? Nie ma w tych działaniach logiki. Fakt przekazania przez księcia paulinom sąsiadujących z miastem dwóch wsi oraz terenu kuźnicy wskazuje raczej na zakończenie zmian osadniczych na tym obszarze, a przede wszystkim na zakończenie formowania się miasta. Inna sprawa, że posunięcie Władysława Opolczyka, jakim było nadanie klasztorowi wsi Częstochowy bezpośrednio przylegającej do miasta, w przyszłości niekorzystnie odbiło się na jego sytuacji. Stworzony został tam konkurencyjny ośrodek — najpierw karczma, a potem de facto osada targowa i rzemieślnicza, która z czasem — już w XVIII wieku — przekształcona została w miasto nazwane Nową Częstochową ${ }^{87}$ Trudno zatem uznać Opolczyka za dobrodzieja miasta i wskazać korzystne dla miasta posunięcia tego księcia.

Właściwe rozpoznanie sytuacji osadniczo-własnościowej wymagało dobrej znajomości realiów danego terenu i zaplanowania regulacji z odpowiednim wyprzedzeniem. W przypadku Częstochowy, jak i ogólnie północnej Małopolski, taką wiedzę posiadał bez wątpienia Kazimierz Wielki, który co najmniej w latach 50. XIV wieku rozpoczął kolonizację wiejską. Wydaje się za to mało prawdopodobne, aby książę Władysław Opolczyk rozpoznał stan i potrzeby osadnictwa nad górną Wartą od razu po objęciu tego obszaru we władanie,

${ }^{86}$ Oczywiście należy odrzucić przypuszczenie J. Laberscheka, że książę przekazał klasztorowi nie swoje wsie. Byłoby to naruszenie prawa. Niewątpliwie zarówno Częstochowa, jak i Krowodrza w 1382 r. były własnością monarszą (J. LABERSCHEK: Uwagi w sprawie fundacji klasztoru jasnogórskiego. W: TenżE: Częstochowa i okolice w średniowieczu. Kraków 2006, s. 95-96).

87 J. Rajman: Rozwój miasta do połowy XVII wieku. W: Czestochowa. Dzieje miasta i Klasztoru..., s. 195-196; F. KiryK, J. Rajman: Częstochowa w latach 1660-1793. W: Częstochowa. Dzieje miasta i Klasztoru..., s. 347-348, 357-365. 
skoro do 1372 roku był zaangażowany w sprawy Królestwa Węgier, a później w sprawy ruskie. Byłoby to natomiast możliwe później, w 2. poł. lat 70. XIV wieku, kiedy książę opolski częściej przebywał na terenie lenna. W jego wypadku można więc co najwyżej mówić o porządkowaniu i kontynuacji procesu lokacyjnego już rozpoczętego.

W tym kontekście oddanie klasztorowi dwu wsi monarszych sąsiadujących z miastem oraz przeniesienie ośrodka parafii do nowo założonego ośrodka można racjonalnie wytłumaczyć całkowitym zamknięciem procesu lokacyjnego miasta Częstochowy w 1382 roku. Zresztą tego samego zdaje się dowodzić przytoczona już informacja $\mathrm{z}$ dokumentu audytora papieskiego, dotycząca sporu o dziesięciny z nowizn mieszczan Częstochowy, który musiał się rozpocząć przed 12 stycznia 1382 roku, a zapewne najpóźniej w 1381 roku. W praktyce oznaczałoby to, że książę opolski musiałby w niespełna 11 lat zaplanować i przeprowadzić cały proces lokacji miasta na „surowym korzeniu”, w najłagodniejszej postaci wymagający wytyczenia co najmniej części ośrodka na niezasiedlonym terenie. Zadanie takie wydaje się nierealne.

Ważną przesłanką, która może pozwolić doprecyzować, kiedy rozpoczęła się lokacja Częstochowy, oraz zidentyfikować osobę inicjatora tego przedsięwzięcia, jest najstarsza informacja o zbudowaniu kościoła w mieście oraz stosunkowo rzadkie wezwanie tej świątyni. Budynek ten musiał być już gotowy w 1382 roku, skoro ówczesny proboszcz częstochowski zgodził się przekazać dotychczasowy kościół parafialny na Górze Starej Częstochowy na rzecz ufundowanego przez księcia Władysława Opolczyka klasztoru Paulinów i przenieść się do świątyni filialnej w Nowej Częstochowie, która odtąd pełniła funkcję ośrodka parafii ${ }^{88}$. Przy założeniu, że to dopiero Władysław Opolczyk zainicjował lokację miasta Częstochowy, należałoby uznać, że kościół zbudowano maksymalnie w 11 lat, a w praktyce w znacznie krótszym czasie. Nie jest to oczywiście niemożliwe, ale wydaje się mało prawdopodobne. Trudno uznać, podobnie jak już to stwierdzono w odniesieniu do Żarek, aby jednym z pierwszych zadań, jakie realizowano w mieście tworzonym na „surowym korzeniu”, była budowa kościoła. Znacznie bardziej uzasadnione jest założenie, że świątynię zaczęto wznosić w końcowym etapie formowania ośrodka.

Patronem częstochowskiej fary jest św. Zygmunt. Wprawdzie najwcześniejsza wzmianka o wezwaniu częstochowskiej świątyni pochodzi dopiero z okresu po 1473 roku, ale o tym, że było to pierwotne patrocinium, przyjęte dla kościoła przy jego erekcji, świadczy najlepiej fakt, że w epoce przedrozbiorowej było ono jedyne ${ }^{89}$. Uważam, że wybór tego dość rzadko występują-

${ }^{88}$ ZDPaul, nr 12; Z. LesZCZyŃSKA-SkRĘTOWA: Częstochowa - klasztor. W: SHGKr, Cz. 1, s. 468; TAż: Częstochowa Stara..., s. 470—471; L. WoJciechowski: Fundacja klasztoru jasnogórskiego. W: Częstochowa. Dzieje miasta i Klasztoru..., s. 153.

${ }^{89}$ Najstarszą wzmiankę o wezwaniu kościoła podaje Jan Długosz (LB, T. 2, s. 220). Wezwanie to jako jedyne dla częstochowskiej fary jest notowane w wizytacjach biskupich 
cego w Polsce patrona dla świątyni nie był sprawą przypadku ${ }^{90}$. Niewątpliwie wiązał się z osobą fundatora, który miał swoje powody, by wybrać tego właśnie świętego. Posiadamy informacje, i to zarówno w źródłach pisanych, jak i materialnych, że św. Zygmunt był bliski właśnie Kazimierzowi Wielkiemu. Wyrazem tego było ufundowanie przez niego słynnej złotej hermy na relikwie tego świętego, przekazanej katedrze w Płocku, zachowanej do dziś. Z przekazu Jana z Czarnkowa dowiadujemy się za to, że ciężko chory król krótko przed śmiercią właśnie za pośrednictwem owego męczennika zanosił modlitwy o uzdrowienie i ślubował odbudowę zrujnowanej katedry płockiej (pw. św. Zygmunta) oraz ufundował uposażenie dla tamtejszych wikariuszy. O zainteresowaniu Władysława Opolczyka kultem św. Zygmunta źródła nie przekazują żadnych informacji ${ }^{91}$. Zarówno więc hipotetyczny czas powstania kościoła, jak i jego wezwanie wskazują na osobę Kazimierza Wielkiego jako jego fundatora, a zatem i założyciela samego miasta.

$\mathrm{Na}$ koniec zostaje jeszcze kwestia tradycji miejskiej. Wprawdzie nie zachował się pierwotny dokument lokacyjny Częstochowy czy jakakolwiek wzmianka o nim, istnieje jednak pewien ślad, który można próbować wiązać z genezą miasta. W 1576 roku król Stefan Batory na prośbę mieszczan z Częstochowy potwierdził zbiorczo wszystkie prawa, przywileje i zwolnienia nadane temu miastu przez poprzedników, wymieniając przy tym imiennie wystawców konfirmowanych dokumentów. Lista władców rozpoczyna się od Ludwika Andegaweńskiego, a dopiero po nim został wymieniony Kazimierz Wielki, po którym wystąpili Władysław Jagiełło i kolejni (bez wyjątku) królowie z dynastii Jagiellonów, aż do Henryka Walezego ${ }^{92}$. Choć w treści nie ma mowy o tym,

z lat 1598: sancti Sigismundi regis, confessoris, 1609: sancti Sigismundi regis et martyris, 1711: ad honorem sancti Sigismundi (AMetrKra, sygn. AVcap. 15, k. 126; sygn. AVcap. 32, s. 48 ; sygn. AV 17, k. 28v).

${ }^{90}$ Było to jedno z rzadziej stosowanych wezwań w Polsce, choć nie najrzadsze. W zestawieniu wezwań kościołów parafialnych w diecezjach krakowskiej i gnieźnieńskiej, sporządzonym przez Eugeniusza Wiśniowskiego dla przełomu XV i XVI w., zaledwie 6 świątyń miało to patrocinium na pierwszym miejscu (4 w diecezji krakowskiej i $2 \mathrm{w}$ gnieźnieńskiej). Por. E. WiśniowSKI: Parafie w średniowiecznej Polsce. Struktura i funkcje społeczne. Lublin 2004, s. 227.

${ }^{91}$ A. Bochnak, J. Pagaczewski: Dary złotnicze Kazimierza Wielkiego dla kościołów polskich. „Rocznik Krakowski” 1934, T. 25, s. 34-78; R. Grodecki: Zgon Kazimierza Wielkiego (1370). W: Mediaevalia. W 50 rocznice pracy naukowej Jana Dąbrowskiego. Warszawa 1960, s. 151-157; A. RoJewsкi: Zarys dziejów kultu św. Zygmunta w diecezji płockiej w okresie przedtrydenckim. „Studia Płockie” 1981, T. 9, s. 103-113; W. Drelicharz: „Filiastra sancti Sigismundi". Z badań nad podaniami genealogicznymi $w$ dziejopisarstwie wieków średnich. W: Cracovia - Polonia - Europa. Studia z dziejów średniowiecza ofiarowane Jerzemu Wyrozumskiemu w sześćdziesiąta piąta rocznicę urodzin i czterdziestolecie pracy naukowej. Kraków 1995, s. 489; J. ŻMUdZIŃSKI: Budownictwo i sztuka..., s. 283; K. NABIAŁEK: Starostwo olsztyńskie..., s. 86; MPH, T. 2, s. 633.

92 Biblioteka Naukowa PAU i PAN w Krakowie, rkps 704, k. 140; K. NABIAŁEK: Starostwo olsztyńskie..., s. 86. 
czego dotyczyły poszczególne przywileje królewskie, wydaje mi się, że dokument króla Ludwika mógł być dyplomem zatwierdzającym wcześniejszy dokument lokacyjny, wydany przez Kazimierza Wielkiego. Przyjęcie takiej interpretacji pozwala zrozumieć przyczynę wymienienia najpierw króla Ludwika, a dopiero po nim Kazimierza Wielkiego, choć inni władcy byli uszeregowani chronologicznie. Wymowny jest także brak wzmianki o jakimkolwiek dokumencie Władysława Opolczyka. O dokument konfirmujący wcześniejszy przywilej Kazimierza Wielkiego mieszczanie częstochowscy mogli się wystarać ze względu na obawę przed unieważnieniem ich praw przez nowego władcę. Hipoteza taka nie jest abstrakcyjna, gdyż w dziejach miast były podobne wypadki. Szczególnie adekwatny wydaje się przykład Wieliczki. Na lokację tego miasta zezwolił Henryk IV Prawy, który bardzo krótko władał ziemią krakowską. Wydany przez tegoż księcia dokument nie zachował się jednak, ale wzmianka o nim znajduje się w dyplomie, zachowanym w oryginale, wydanym przez następcę na tronie krakowskim - Przemysła II. W kontrakcie lokacyjnym wystawionym 25 lipca 1290 roku, a więc zaledwie miesiąc po śmierci Henryka IV, nowy monarcha przytoczył i potwierdził jedynie zasadniczą treść pierwotnego kontraktu, bez podania daty i miejsca wydania ${ }^{93}$. Z nieco podobną sytuacją mamy do czynienia również w małopolskim Wojniczu. Choć lokacja miasta nastąpiła najpewniej za Bolesława Wstydliwego, a Kazimierz Wielki, wydając przywilej na wójtostwo w 1349 roku, jednocześnie przyznał miastu prawo magdeburskie, to dopiero dokument Ludwika z 1381 roku był traktowany jako dokument lokacyjny i przedkładany lustratorom ${ }^{94}$.

IV. Podsumowując rozważania na temat genezy miasta Częstochowy, a w szczególności próbę wyjaśnienia, kto i kiedy rozpoczął to przedsięwzięcie, wydaje się, że liczne przesłanki pozwalają uznać Kazimierza Wielkiego za najbardziej prawdopodobnego inicjatora lokacji. Wbrew stanowisku przyjętemu w najnowszej monografii miasta nie ma zbyt wielu podstaw do tego, by przypisać to dzieło księciu Władysławowi Opolczykowi. Wszystkie argumenty przemawiają tu za planową i rozłożoną na wystarczająco długi okres akcją kolonizacyjną Kazimierza Wielkiego, poprzedzoną lokacjami osad wiejskich, a zwieńczoną założeniem miasta. Dzieło kolonizacji ziem nad górną Wartą podjęte zostało przez Kazimierza Wielkiego najpóźniej w latach 50. XIV wieku.

${ }^{93}$ Kodeks dyplomatyczny wielicki. Lwów 1872, s. 1-2; Katalog zbioru dokumentów pergaminowych Biblioteki Jagiellońskiej. Oprac. K. NabiaŁeK, W. Świeboda, M. ZdaneK, współpraca R. TAtARzyŃSKi. Red. K. NABialeK. T. 1: Katalog dokumentów. Kraków 2014, nr 4, s. 5; J. Piotrowicz: Dzieje miasta Wieliczki w wiekach średnich. W: Wieliczka. Dzieje miasta (do roku 1980). Kraków 1990, s. 63-72, 114 (przyp. 12); F. SikorA: Wójtostwo wielickie w średniowieczu. „Annales Academiae Paedagogicae Cracoviensis” 2004, Folia 21, Studia historica III, s. 203-204; K. NabialeK: Starostwo olsztyńskie..., s. 85-86.

${ }^{94}$ K. Nabialek: Dzieje Wojnicza od XVI do polowy XVII w. W: W. Krawczuk, P. Miodunka, K. Nabialek: Dzieje Wojnicza od XVI do XVIII wieku. Wojnicz 2009, s. 71-73. 
Dotyczy to również okolic Częstochowy i Mstowa. Akcja kolonizowania na prawie niemieckim obszaru w najbliższej okolicy Częstochowy - co istotne - po obu stronach Warty jest uchwytna źródłowo. Na prawym brzegu Warty prawo niemieckie uzyskała wieś Siedlec (1354), a nie można wykluczyć, że także za panowania tego władcy doszło do reorganizacji wsi Mirów. Na lewym brzegu zaś dokonano lokacji kilku wsi: Rudniki (1349), Wyczerpy (1356), dwóch wsi w dziedzictwie zwanym Częstochowa (1356) oraz Rększowice (1369). Bardzo możliwe, że za rządów Kazimierza Wielkiego lokowane zostały też wsie Konopiska oraz Wierzchowisko. W całym przedsięwzięciu, które król podjął w północnej Małopolsce, jak się wydaje, kluczowe znaczenie miało zorganizowanie przeprawy przez Wartę i założenie w jej pobliżu miasta. Było to konieczne dla dobrego skomunikowania terenów na obu brzegach tej rzeki, wchodzących w skład olsztyńskiego dystryktu zamkowego, a w szerszym ujęciu - dla zorganizowania nowego przebiegu drogi łączącej Kraków z Wielkopolską i Śląskiem. Kazimierz Wielki musiał zatem zaplanować lokację miasta jeszcze przed rozpoczęciem kolonizacji wiejskiej. Nawet jeżeli przyjęlibyśmy, że to książę opolski formalnie wystawił dla Częstochowy dokument lokacyjny, to jego działanie stanowiłoby kontynuację czy wręcz zwieńczenie melioracji osadniczej tego obszaru, rozpoczętej przez króla Kazimierza Wielkiego. Mimo że we fragmencie Kroniki katedralnej krakowskiej opisującym dokonania Kazimierza Wielkiego nie ma mowy o lokacji Częstochowy, to jednak ten brak nie może stanowić argumentu decydującego. Wystarczy wskazać, że nie ma tam również wzmianki o założeniu Przyrowa, dla którego zachował się kontrakt lokacyjny wystawiony przez tegoż króla w 1369 roku. Być może brak Częstochowy w katalogu inwestycji budowlanych i fundacyjnych ostatniego Piasta, podobnie jak w wypadku Przyrowa, świadczy o tym, że w chwili spisania kroniki proces formowania się miasta był jeszcze niedokończony.

\section{Bibliografia}

\section{Źródla rękopiśmienne}

Archiwum Główne Akt Dawnych w Warszawie: Archiwum Skarbu Koronnego, dz. XLVI, sygn. 42; Metryka Koronna, sygn. 45.

Archiwum Kurii Metropolitarnej w Krakowie: Acta visitaciones capituli, sygn. AVcap. 15, 32, 48; Acta visitaciones, sygn. AV 17.

Biblioteka Naukowa PAU i PAN w Krakowie: rkps 704. 


\section{Źródła drukowane}

Joannis Dlugosz senioris canonici Cracoviensis Liber beneficiorum dioecesis Cracoviensis.

Ed. L. Łętowski. T. 1-3. In: Opera Omnia. T. 7-9. Ed. A. Przeździecki. Cracoviae $1883-1884$.

Kodeks dyplomatyczny wielicki. Lwów 1872.

Liber receptorum et expensarum Petri Stephani 1373-1375. Ed. S. Szczur. In: Monumenta Poloniae Vaticana. T. 9. Vol. 3. Cracoviae 1994.

Lustracja cet i myt małopolskich z 1565 roku. Wyd. B. WyrozumsKa, przy współpracy M. STARZYŃSKIEGO, indeksy oprac. P. WienCIERZ. Kraków 2019.

Lustracja dróg województwa krakowskiego z roku 1570. Wyd. B. WyrozumsKa. Wrocław 1971. Lustracja województwa krakowskiego 1564. Wyd. J. MaŁeCKI. Cz. 2. Kraków 1964.

Monumenta Poloniae Historica. T. 2. Ed. A. Bielowski. Lwów 1872.

Urzędowe nazwy miejscowości i obiektów fizjograficznych. Z. 202: Powiat częstochowski i powiat miejski Częstochowa, województwo katowickie. [Warszawa] 1972.

Zbiór dokumentów katedry i diecezji krakowskiej. Cz. 1. Wyd. S. Kuraś. Lublin 1965.

Zbiór dokumentów małopolskich. Cz. 4. Wyd. S. Kuraś, I. SuŁKowsKa-Kuraś. KrakówWrocław 1969.

Zbiór dokumentów zakonu oo. paulinów w Polsce. Oprac. ks. J. FiJaŁeK. Z. 1: (1328-1464). Kraków 1938.

\section{Opracowania}

Antoniewicz M.: Heraldyka Częstochowy w okresie przedrozbiorowym. W: Częstochowa. Dzieje miasta i Klasztoru Jasnogórskiego. T. 1: Okres staropolski. Red. F. KIRYK. Częstochowa 2002.

Antoniewicz M.: Herby miast województwa częstochowskiego. Częstochowa 1984.

Antoniewicz M.: Narodziny miasta. W: Częstochowa. Dzieje miasta i Klasztoru Jasnogórskiego. T. 1: Okres staropolski. Red. F. KIRYк. Częstochowa 2002.

AnTONIEwicz M.: Niektóre problemy genezy miasta Żarek na tle politycznych dziejów regionu w XIV wieku. W: Szkice do dziejów Żarek. W 600-lecie miasta. Red. H. RolA. Katowice 1984.

Antoniewicz M.: Podstawy i zakres władzy księcia Władysława II opolskiego w ziemi wieluńskiej oraz północno-zachodniej Małopolsce. W: Książę Władysław Opolczyk. Fundator klasztoru Paulinów na Jasnej Górze w Częstochowie. Red. M. Antoniewicz, J. ZBudnieWEK. Warszawa 2007.

Antoniewicz M.: Przeszłość Żarek. Powstanie i rozwój miasta na przestrzeni sześciu wieków. Częstochowa 1982.

Antoniewicz M.: Subregion częstochowski w średniowieczu (XIV-XV wiek). W: Częstochowa i jej miejsce w kulturze polskiej. Częstochowa 1990.

Antoniewicz M.: W sprawie genezy miasta Żarki [kilka uwag po artykule J. Laberscheka i recenzji Z. Nogi]. „Studia Historyczne” 1987, T. 30, nr 2.

Baliński M.: Pielgrzymka do Jasnej Góry w Częstochowie odbyta przez pątnika z XIX wieku. Warszawa 1846. 
BERDECKA A.: Lokacje i zagospodarowanie miast królewskich w Małopolsce za Kazimierza Wielkiego (1333-1370). Wrocław 1982.

Bochnak A., Pagaczewski J.: Dary złotnicze Kazimierza Wielkiego dla kościołów polskich. „Rocznik Krakowski” 1934, T. 25.

Braun J.: Częstochowa. Architektura i urbanistyka. Warszawa 1977.

Braun J.: Częstochowa. Zarys architektoniczny i urbanistyczny. Warszawa 1959.

Częstochowa. Dzieje miasta i Klasztoru Jasnogórskiego. T. 1: Okres staropolski. Red. F. KIRYK. Częstochowa 2002.

Drelicharz W.: „Filiastra sancti Sigismundi”. Z badań nad podaniami genealogicznymi $w$ dziejopisarstwie wieków średnich. W: Cracovia - Polonia - Europa. Studia z dziejów średniowiecza ofiarowane Jerzemu Wyrozumskiemu w sześćdziesiąta piąta rocznicę urodzin i czterdziestolecie pracy naukowej. Kraków 1995.

Du CANGe et alii: Glossarium mediae et infimae latinitatis. Dostępne w Internecie: http:// ducange.enc.sorbonne.fr/MERICA1 [data dostępu: 21.11.2018].

Gawlas S.: O ksztatt zjednoczonego Królestwa. Niemieckie władztwo terytorialne a geneza społeczno-ustrojowej odrębności Polski. Wyd. 2. Warszawa 2000.

Gawlas S.: Polska Kazimierza Wielkiego a inne monarchie Europy Środkowej - możliwości i granice modernizacji władzy. W: Modernizacja struktur władzy w warunkach opóźnienia. Europa Środkowa i Wschodnia na przełomie średniowiecza i czasów nowożytnych. Red. M. Dygo, S. Gawlas, H. Grala. Warszawa 1999.

Gawlas S.: Uwagi o polityce miejskiej Kazimierza Wielkiego. W: Aetas media, aetas moderna. Studia ofiarowane profesorowi Henrykowi Samsonowiczowi w siedemdziesiąta rocznice urodzin. Warszawa 2000.

Grodecki R.: Zgon Kazimierza Wielkiego (1370). W: Mediaevalia. W 50 rocznice pracy naukowej Jana Dąbrowskiego. Warszawa 1960.

Haisig M.: Herb miasta Częstochowy. Jego geneza i symbolika. „Ziemia Częstochowska” 1967, T. $6-7$.

KAMIŃSKA K.: Lokacje miast na prawie magdeburskim na ziemiach polskich do 1370 r. (studium historycznoprawne). Torun 1990.

Katalog zbioru dokumentów pergaminowych Biblioteki Jagiellońskiej. Oprac. K. NabiaŁeK, W. Świeboda, M. ZdaneK, współpraca R. Tatarzyński. Red. K. NabiaŁeK. T. 1: Katalog dokumentów. Kraków 2014.

KIRYK F.: Miasto średniowieczne. W: Proszowice. Zarys dziejów do 1939 roku. Red. F. KiryK. Kraków 2000.

KiRYk F.: Polityka miejska Kazimierza Wielkiego w Małopolsce. W: Problemy dziejów i konserwacji miast zabytkowych. Materiaty II Sympozjum Miast Kazimierzowskich w Radomiu i Kazimierzu Dolnym 23-24 września 1988 roku. Red. R. Szczygiet. Radom-Kazimierz Dolny 1990.

KIRYK F.: Z dziejów urbanizacji Wyżyny Krakowsko-Częstochowskiej w średniowieczu. W: Zróżnicowanie i przemiany środowiska przyrodniczo-kulturowego Wyżyny Krakowsko-Częstochowskiej. Red. J. Partyka. T. 2: Kultura. Ojców 2004.

Kiryk F., Rajman J.: Częstochowa w latach 1660-1793. W: Częstochowa. Dzieje miasta i Klasztoru Jasnogórskiego. T. 1: Okres staropolski. Red. F. KIRYк. Częstochowa 2002.

Kos T.: Fundacja klasztoru jasnogórskiego w świetle nowej interpretacji źródet. Kraków 2002.

Krakowski S.: Dzieje Częstochowy od wieku XII do połowy XIX. W: Dzieje Częstochowy od zarania do czasów współczesnych. Katowice 1964.

Krakowski S.: „Region częstochowski” w wiekach XII-XVIII. Prawidłowości i specyfika procesów urbanizacyjnych. W: Słowianie w dziejach Europy. Studia historyczne ku 
uczczeniu 75 rocznicy urodzin i 50-lecia pracy naukowej profesora Henryka Łowmiańskiego. Poznań 1974.

Krakowski S.: Stara Częstochowa. Studia nad geneza, ustrojem i struktura ludnościowa i gospodarcza Częstochowy (1220-1655). Częstochowa 1948.

KRASNOWOLSKI B.: Lokacyjne uktady urbanistyczne na obszarze ziemi krakowskiej w XIII i XIV wieku. Cz. 1-2. Kraków 2004.

Kuraś S.: Przywileje prawa niemieckiego miast $i$ wsi małopolskich XIV-XV wieku. Wrocław 1971.

Kuraś S., rec.: J. Luciński: Majątki ziemskie panującego w Małopolsce do 1385 roku, Poznań 1967. „Studia Historyczne” 1968, T. 11.

LABERSCHEK J.: Częstochowski zespót osadniczy w średniowieczu. „Almanach Częstochowy” 2002.

LABERSCheK J.: Dzieje średniowiecznego Lelowa. Lelów 2018.

LABERSCHeK J.: Grabówka. W: Stownik historyczno-geograficzny województwa krakowskiego $w$ średniowieczu. Cz. 2. Oprac. J. Kurtyka, J. Laberschek, Z. Leszczyńska-Skrętowa, F. Sikora. Red. F. Sikora. Wrocław-Kraków 1989-1993.

LABERSCHEK J.: Kocinka. W: Stownik historyczno-geograficzny województwa krakowskiego w średniowieczu. Cz. 2. Oprac. J. Kurtyka, J. LaberscheK, Z. LeszczyńsKa-Skrętowa, F. SiKora. Red. F. SiKora. Wrocław-Kraków 1989-1993.

LABERSCHeK J.: Komorów. W: Stownik historyczno-geograficzny województwa krakowskiego $w$ średniowieczu. Cz. 2. Oprac. J. Kurtyka, J. Laberschek, Z. Leszczyńska-Skrętowa, F. SiKora. Red. F. SiKora. Wrocław-Kraków 1989-1993.

LABERSCHEK J.: Konopiska. W: Stownik historyczno-geograficzny województwa krakowskiego $w$ średniowieczu. Cz. 2. Oprac. J. Kurtyka, J. Laberschek, Z. Leszczyńska-Skrętowa, F. SiKora. Red. F. SiKora. Wrocław-Kraków 1989-1993.

LABERSCHEK J.: Kromołów. W: Stownik historyczno-geograficzny województwa krakowskiego w średniowieczu. Cz. 3. Oprac. W. Bukowski, J. Kurtyka, J. LaberscheK, Z. LeszczyŃSKa-Skrętowa, A. Marzec, F. Sikora, M. Wilamowski, M. Wolski. Red. F. Sikora. Kraków 1994-2003.

LABERSCHeK J.: Lelów - miasto. W: Stownik historyczno-geograficzny województwa krakowskiego w średniowieczu. Cz. 3. Oprac. W. Bukowski, J. Kurtyka, J. LaberscheK, Z. Leszczyńska-Skrętowa, A. Marzec, F. Sikora, M. Wilamowski, M. Wolski. Red. F. SiKORA. Kraków 1994-2003.

LaberscheK J.: Mirów [parafia Mstów]. W: Stownik historyczno-geograficzny województwa krakowskiego w średniowieczu. Cz. 4. Oprac. W. Bukowski, J. LaberscheK, Z. Leszczyńska-Skrętowa, A. Marzec, M. Mikula, K. Nabialek, F. Sikora, J. Szyszka, M. Wolski, M. ZdAneK. Red. W. Bukowski. Wrocław-Kraków 2006-2014.

LABERSCHEK J.: Na pograniczu krakowsko-opolskim. Częstochowa pod rzadami Władystawa Opolczyka. W: Bunt wójta Alberta. Kraków i Opole we wzajemnych zwiazkach w XIV wieku. Red. J. Rajman. Kraków 2013.

LABerscheK J.: Nowe spojrzenie na poczatki Częstochowy. W: J. LABerscheK: Częstochowa i jej okolice w'średniowieczu. Kraków 2006.

LABERSCHeK J.: Nowe spojrzenie na początki miasta Częstochowy. „Almanach Częstochowy” 1994.

Laberschen J.: Początki Częstochowy na tle stosunków osadniczych. W: Częstochowa. Dzieje miasta i Klasztoru Jasnogórskiego. T. 1: Okres staropolski. Red. F. KIRYK. Częstochowa 2002.

LABerscher J.: Początki i rozwój miasta Szczekociny do końca XV wieku. Uwagi do genealogii Szczekockich herbu Odroważ. W: Patientia et tempus. Księga jubileuszowa dedykowana 
doktorowi Marianowi Korneckiemu. Red. O. Dyba, S. Kolodziejski, R. Marcinek. Kraków 1999.

LaberscheK J.: Poczatki miasta Żarki i pierwszy wiek jego istnienia. „Studia Historyczne” 1986, T. 29, nr 3.

LABERSCHEK J.: Rozwój sieci parafialnej w dekanacie lelowskim do 1500 r. W: Księga jubileuszu stulecia Diecezji Kieleckiej (1883-1983). Kielce 1986.

LABERSCHEK J.: Rycerstwo Częstochowy i jej najbliższych okolic (przetom XIV i XV wieku). „Teki Krakowskie” 1997, T. 5.

LaberscheK J.: Sieć osadnicza okolic Mstowa i Lelowa w I polowie XIII wieku. Problem granic opola mstowskiego. „Studia Historyczne” 1991, T. 34, nr 4.

LABERSCHEK J.: Uwagi w sprawie fundacji klasztoru jasnogórskiego. W: J. LABERSCHEK: Częstochowa i okolice w średniowieczu. Kraków 2006.

LABERSCHEK J.: W czasach piastowskich i jagiellońskich. W: Kłobuck. Dzieje miasta i gminy (do roku 1939). Red. F. KIRYK. Kraków 1998.

LABERSCHEK J.: Wójtostwo częstochowskie w czasach piastowskich i jagiellońskich. „Almanach Częstochowy" 2004.

LABERSCHEK J.: Zasięg i charakterystyka rzadów Władysława Opolczyka w pótnocno-zachodniej części ziemi krakowskiej 1370-1391. „Rocznik Muzeum Okręgowego w Częstochowie. Historia" 1985 , z. 1.

LABERSCHeK J., rec.: Częstochowa i jej miejsce w kulturze polskiej, Częstochowa 1990. „Kwartalnik Historyczny” 1991, T. 98.

LeSZCZyŃSKA-SKRęTOWA Z.: Częstochowa - klasztor. W: Stownik historyczno-geograficzny województwa krakowskiego w średniowieczu. Cz. 1. Oprac. J. LABERSCHEK, Z. LeSZCZyŃska-Skrętowa, F. Sikora, J. Wiśniewski. Red. J. Wiśniewski. Wrocław 19801986.

Leszczyńska-Skrętowa Z.: Częstochowa Stara. W: Stownik historyczno-geograficzny województwa krakowskiego w średniowieczu. Cz. 1. Oprac. J. LABERSCHEK, Z. LeszCZYŃSKa-Skrętowa, F. Sikora, J. WiŚniewski. Red. J. Wiśniewski. Wrocław 1980-1986.

Lisowicz D.: Mate miasta przy granicy śląsko-małopolskiej w XIV w. Geneza - funkcje warunki rozwoju. W: Bunt wójta Alberta. Kraków i Opole we wzajemnych zwiąkach w XIV wieku. Red. J. Rajman. Kraków 2013.

LuCiŃSKi J.: Lokacje wsi i miast monarszych w Małopolsce do 1385 r. „Czasopismo Prawno-Historyczne" 1965, T. 17, nr 2.

Marek R., Wojcieszak M., Wojcieszak J.: Wyniki badań archeologicznych na terenie parafii pw. św. Zygmunta w Częstochowie, województwo ślaskie. W: Badania archeologiczne na Górnym Śląsk i ziemiach pogranicznych w latach 2011-2012. Katowice 2014.

MaSŁowsKi J.: Kolonizacja wiejska na prawie niemieckim $w$ województwach sieradzkim, tęczyckim, na Kujawach i w ziemi dobrzyńskiej. „Roczniki Historyczne” 1937, T. 13.

Mıodkowska-Przepiórowska I.: Ratusz w Starej Częstochowie nad Warta w świetle badań archeologicznych. „Rocznik Muzeum Częstochowskiego” 2018, T. 17.

MŁodKowska-PrzePiórowska I.: Wyniki archeologicznych badań wykopaliskowych na Starym Rynku w Częstochowie (stanowisko 49), województwo śląskie. W: Badania archeologiczne na Górnym Ślasku i ziemiach pogranicznych w latach 2011-2012. Katowice 2014.

NabialeK K.: Dzieje miasta Olsztynek koło Częstochowy od założenia do połowy XVII wieku. W: „Zeszyty Naukowe Uniwersytetu Jagiellońskiego”, Nr 1256. Prace historyczne, z. 129. Kraków 2002.

Nabialek K.: Dzieje Wojnicza od XVI do połowy XVII w. W: W. Krawczuk, P. Miodunka, K. NabiaŁeK: Dzieje Wojnicza od XVI do XVIII wieku. Wojnicz 2009. 
NabiaŁeK K.: Młodów. W: Słownik historyczno-geograficzny województwa krakowskiego $w$ średniowieczu. Cz. 4. Oprac. W. Bukowski, J. LaberscheK, Z. LeszczyńsKa-SKrętowa, A. Marzec, M. Mikula, K. Nabialek, F. Sikora, J. Szyszka, M. Wolski, M. ZdaNEK. Red. W. BukowsKi. Wrocław-Kraków 2006-2014.

NabialeK K.: Starostwo olsztyńskie od XIV do połowy XVII wieku. Kraków 2012.

Nabialek K.: Średniowieczne dzieje miasta Mrzygłód. Przyczynek do kolonizacji pótnocnej Małopolski w późnym średniowieczu. W: „Średniowiecze Polskie i Powszechne”. T. 7 (11). Red. J. Sperka, B. Czwojdrak. Katowice 2015.

Noga Z., rec.: Szkice do dziejów Żarek. W 600-lecie miasta, red. H. Rola. Katowice 1984. „Studia Historyczne” 1986, T. 29, nr 3.

PieradzKa K.: Fundacja klasztoru jasnogórskiego w Częstochowie w 1382 r. Kraków 1939.

Piotrowicz J.: Dzieje miasta Wieliczki w wiekach średnich. W: Wieliczka. Dzieje miasta (do roku 1980). Kraków 1990.

Rajman J.: Rozwój miasta do połowy XVII wieku. W: Częstochowa. Dzieje miasta i Klasztoru Jasnogórskiego. T. 1: Okres staropolski. Red. F. KIRYK. Częstochowa 2002.

RoJewski A.: Zarys dziejów kultu św. Zygmunta w diecezji płockiej w okresie przedtrydenckim. „Studia Płockie” 1981, T. 9.

Rymut K.: Kawodrza. W: Nazwy miejscowe Polski. Historia. Pochodzenie. Zmiany. Red. K. Rymut. T. 4: $J-K n$. Kraków 2001.

Rymut K.: Krowodrza. W: Nazwy miejscowe Polski. Historia. Pochodzenie. Zmiany. Red. K. Rymut. T. 5: Ko-Ky. Kraków 2003.

Rymut K.: Nazwy miejscowe pótnocnej części dawnego województwa krakowskiego. Wrocław 1967.

SiKora F.: Ropczycki zespół osadniczy w średniowieczu. Z badań nad kazimierzowskim modelem osadniczo-urbanizacyjnym. „Teki Krakowskie” 1996, T. 3.

Sikora F.: Wójtostwo wielickie w średniowieczu. „Annales Academiae Paedagogicae Cracoviensis" 2004, Folia 21, Studia historica III.

Sikora F. przy współpracy J. LABERSCHEKA: Krzepice - miasto. W: Stownik historyczno-geograficzny województwa krakowskiego w średniowieczu. Cz. 3. Oprac. W. Bukowski, J. Kurtyka, J. Laberschek, Z. Leszczyńska-Skrętowa, A. Marzec, F. Sikora, M. WiLAMOWski, M. Wolski. Red. F. Sikora. Kraków 1994-2003.

Stownik historyczno-geograficzny ziemi wieluńskiej w średniowieczu. Oprac. R. Rosın. Warszawa 1963.

Stownik taciny średniowiecznej w Polsce. T. 8, z. 4. Kraków 2006.

SPerka J.: Dzieje Będzina w XIV-XV w. W: Będzin 1358-2008. T. 2: Od pradziejów do rozbiorów. Red. J. Sperka. Będzin 2008.

SPERKa J.: Władysław książę opolski, wieluński, kujawski, dobrzyński, pan Rusi, palatyn Węgier i namiestnik Polski (1326/1330—8 lub 18 maja 1401). Kraków 2012.

Wartalska E.: Dzieje Częstochówki (1220-1655). W: Częstochowa i jej miejsce w kulturze polskiej. Częstochowa 1990.

Wiśniowski E.: Parafie $w$ średniowiecznej Polsce. Struktura i funkcje społeczne. Lublin 2004.

Wojciechowski L.: Fundacja klasztoru jasnogórskiego. W: Częstochowa. Dzieje miasta i Klasztoru Jasnogórskiego. T. 1: Okres staropolski. Red. F. KIRYK. Częstochowa 2002.

Żmudziński J.: Budownictwo i sztuka w Częstochowie do połowy XVII wieku. W: Częstochowa. Dzieje miasta i Klasztoru Jasnogórskiego. T. 1: Okres staropolski. Red. F. KiRYK. Częstochowa 2002. 


\title{
Karol Nabiatek
}

\author{
Who Founded the Town of Częstochowa? \\ On the Urbanization of the Lesser Poland in the $14^{\text {th }}$ Century
}

\section{Summary}

The article is an attempt to verify the circumstances concerning the founding of the town of Częstochowa, in particular the person of the initiator of the location. Historiographers have argued about the identity of the town's founder for years, with some favoring Duke Vladislaus II of Opole and others King Casimir III the Great. In the most recent monograph of Częstochowa (2002), the assumption has been made that the founder of the city was indeed the Duke of Opole, even though there are not many grounds to make such claim. The main premise seems to be the oldest mention of the city, dating back to the rule of Vladislaus II (1377). However, there exists significantly more proof that points to a pre-planned and executed over time expansion strategy initiated by Casimir III, which was preceded by the location of villages and crowned with the founding of the city itself. The foundation of Częstochowa can be, then, regarded as part of Casimir's modernization effort in the Kingdom of Poland, since, in order to build a new route connecting Cracow with Greater Poland and Silesia, it was crucial to build a crossing over the river Warta in the vicinity of the Częstochowa village and the subsequent location of the city.

Key words: Częstochowa, location, urbanization, Casimir III the Great, cities

\section{Karol Nabiatek}

\section{Wer hat die Stadt Częstochowa gegründet? Ein Beitrag zur Urbanisierung von Kleinpolen im 14. Jahrhundert}

\section{Zusammenfassung}

Der Artikel ist ein Versuch, die Umstände der Entstehung der Stadt Częstochowa und insbesondere die Hinweise auf den Initiator ihrer Lokalisation zu überprüfen. In der Geschichtsschreibung gibt es seit Jahren einen Streit um die Person des Stadtgründers. Es werden hier zwei Personen in Betracht gezogen - Fürst Wladislaus von Oppeln und Kasimir der Große. In der neuesten Monographie über Częstochowa (2002) geht man davon aus, dass der Herzog von Oppeln ein Stadtgründer war, obwohl es nicht so viele Gründe dafür gibt, um gerade ihm die Lokalisation von Częstochowa zuzuschreiben. Als die Hauptvoraussetzung gilt die älteste Erwähnung über die Stadt während der Herrschaft von Wladislaus von Oppeln auf diesem Gebiet (1377). Eine Reihe von Argumenten spricht aber für die geplante und über einen ausreichend langen Zeitraum dauernde Kolonisierungsaktion von Kasimir dem Großen, der die Lokalisation der ländlichen Siedlungen vorangegangen ist und die mit der Lokalisation der Stadt gekrönt war. Die Gründung von Częstochowa passt in den von Kasimir dem Großen initiierten Prozess der Modernisierung des Königreiches Polen. Entscheidend für einen neuen Verlauf der Straße, die Krakau mit Großpolen und Schlesien verbinden sollte, waren die Organisierung eines Übergangs über die Warthe in der Nähe des Dorfes Częstochowa und die Gründung einer Stadt in seiner Nähe.

Schlüsselwörter: Częstochowa, Lokalisation, Urbanisierung, Kasimir der Große, Städte 